\title{
Citrus Extract as a Perspective for the Control of Dyslipidemia: A Systematic Review With Meta-Analysis From Animal Models to Human Studies
}

\author{
Betina M. R. Carvalho ${ }^{1}$, Laranda C. Nascimento ${ }^{1}$, Jessica C. Nascimento ${ }^{1}$, \\ Vitória S. dos S. Gonçalves ${ }^{2}$, Patricia K. Ziegelmann ${ }^{3}$, Débora S. Tavares ${ }^{4}$ and \\ Adriana G. Guimarães ${ }^{5 *}$
}

${ }^{1}$ Programa de Pós-Graduação em Ciências Aplicadas à Saúde, Universidade Federal de Sergipe, Lagarto, Brazil, ${ }^{2}$ Departamento de Química, Universidade Federal de Sergipe, São Cristóvão, Brazil, ${ }^{3}$ Departamento de Estatística, Programa de Pós-graduação em Epidemiologia, Universidade Federal do Rio Grande do Sul, Porto Alegre, Brazil, ${ }^{4}$ Departamento de Educação em Saúde, Universidade Federal de Sergipe, Lagarto, Brazil, ${ }^{5}$ Departamento de Farmácia, Universidade Federal de Sergipe, São Cristóvão, Brazil

\section{OPEN ACCESS}

Edited by: Irwin Rose Alencar de Menezes, Regional University of Cariri, Brazil

Reviewed by: Amir Hadi,

Isfahan University of Medical Sciences, Iran Praveen Kumar M, Nference, India

*Correspondence: Adriana G. Guimarães adrianagibara@hotmail.com adrianagibara@pq.cnpq.br

Specialty section: This article was submitted to Gastrointestinal and Hepatic Pharmacology,

a section of the journal

Frontiers in Pharmacology

Received: 26 November 2021 Accepted: 10 January 2022

Published: 14 February 2022

Citation:

Carvalho BMR, Nascimento $L C$ Nascimento JC, Gonçalves VSS, Ziegelmann PK, Tavares DS and Guimarães AG (2022) Citrus Extract as a Perspective for the Control of

Dyslipidemia: A Systematic Review With Meta-Analysis From Animal Models to Human Studies. Front. Pharmacol. 13:822678. doi: 10.3389/fphar.2022.822678
This study aims to obtain scientific evidence on the use of Citrus to control dyslipidemia. The surveys were carried out in 2020 and updated in March 2021, in the PubMed, Scopus, LILACS, and SCiELO databases, using the following descriptors: Citrus, dyslipidemias, hypercholesterolemia, hyperlipidemias, lipoproteins, and cholesterol. The risk of bias was assessed according to the Cochrane methodology for clinical trials and ARRIVE for preclinical trials. A meta-analysis was performed using the application of $R$ software. A total of 958 articles were identified and 26 studies demonstrating the effectiveness of the Citrus genus in controlling dyslipidemia were selected, of which 25 were included in the meta-analysis. The effects of Citrus products on dyslipidemia appear consistently robust, acting to reduce total cholesterol, LDL, and triglycerides, in addition to increasing HDL. These effects are associated with the composition of the extracts, extremely rich in antioxidant, as flavonoids, and that act on biochemical targets involved in lipogenesis and beta-oxidation. The risk of bias over all of the included studies was considered critically low to moderate. The meta-analysis demonstrated results favorable to control dyslipidemia by Citrus products. On the other hand, high heterogeneity values were identified, weakening the evidence presented. From this study, one can suggest that Citrus species extracts are potential candidates for dyslipidemia control, but more studies are needed to increase the strength of this occurrence.

Keywords: dyslipidemia, citrus, hyperlipidemia, flavonoids, cholesterol

Systematic Review Registration: [https:/www.crd.york.ac.uk/prospero/display_record.php?ID= CRD42019121238], identifier [PROSPERO 2019 CRD42019121238].

\section{INTRODUCTION}

Dyslipidemia has high rates of occurrence in the world population (Pirillo et al., 2021), being closely related to obesity, metabolic syndrome (Mach et al., 2020), atherosclerosis (Wiggins et al., 2019), 
coronary heart disease (Zhao et al., 2021), increased susceptibility to cancer (Khan et al., 2021), and more recently increased mortality and severity of COVID-19 (Atmosudigdo et al., 2021). This disorder is characterized by changes in the lipid profile, including an increase in total serum cholesterol, lowdensity lipoprotein (LDL-c), and triglycerides, as well as a decrease in high-density lipoprotein (HDL-c) rates in the blood (Fruchart et al., 2008). The relationships between these markers have been used as indicators of insulin resistance and metabolic disorders (Sowndarya et al., 2021), in addition to atherosclerosis and coronary heart disease (Abid et al., 2021). However, inflammation markers such as us-CRP (high serum sensitivity C-reactive protein) can also be considered important indicators to estimate the severity and risk of coronary artery disease (Patil et al., 2020). Although there are therapeutic options for the treatment of dyslipidemias, these are not fully effective, due to non-adherence to treatment by various factors such as adverse effects, intolerance, regimen complexity, and imperceptible benefits, besides the need to combine drugs to improve the clinical condition (Schulz, 2006; Ingersgaard et al., 2020). On the other hand, lipid-lowering drugs are still inaccessible to the majority of the population in low-income countries (Pirillo et al., 2021), making the search for new strategies to control dyslipidemia necessary.

In this sense, searching for new treatment strategies for this important health problem is necessary. In this perspective, several plants and natural products have been studied regarding their effects on dyslipidemia control (Ballard et al., 2019; Adel Mehraban et al., 2021); among them, the species of the genus Citrus (Lamiquiz-Moneo et al., 2020) stand out. Belonging to the Rutaceae family, the genus Citrus is widely distributed in tropical and subtropical regions (Manuel et al., 2020) and contains several substances with biological and nutritional potential, such as fibers (e.g., pectin), vitamins, and bioactive compounds, with emphasis on the flavonoids (Alam et al., 2013; Rafiq et al., 2018). Naringin, naringenin, nobiletin, narirutin, and hesperidin correspond to the most frequently found flavonoids. They have pronounced antioxidant and anti-inflammatory activities (Tripoli et al., 2007; Craft et al., 2012), in addition to being effective in controlling metabolic syndromes, lipid changes, and obesity (Geleijnse et al., 1999; Lee et al., 2001; Gattuso et al., 2007; Alam et al., 2013; Sahebkar, 2017; Ballard et al., 2019).

Thus, this review sought to compile the scientific findings that demonstrate the effect of Citrus extracts on the control of serum lipid levels, measuring the size of the effect through meta-analysis.

\section{MATERIAL AND METHODS}

\section{Focused Question}

The question to be answered was established from the bibliographic survey "Are species of the genus Citrus effective in reducing dyslipidemia?" conducted through four steps: (Pirillo et al., 2021) identification of the use of the Citrus species, (Mach et al., 2020) identification of the pathology to be applied (dyslipidemia), (Wiggins et al., 2019) definition of the types of studies included (preclinical and clinical), and (Zhao et al., 2021) definition of the target outcome to be analyzed, which is the lipid profile, building the PICOS strategy (patient or pathology, intervention, control, other outcomes, and the type of study). PICOS is highlighted as follows: P: dyslipidemia; I: species of the genera Citrus (extract); C: untreated or placebo-treated and hyperlipidemia-induced group; $\mathrm{O}$ : blood lipid levels; and $\mathrm{S}$ : preclinical or clinical studies.

\section{Review Writing and Registration of Protocols}

The writing of this systematic review was based on the recommendations of the Preferred Reporting Items for Systematic Reviews and Meta-Analyses (PRISMA) (Page et al., 2021) tool. In addition, the instrument that guides how the experimental studies should be analyzed was ARRIVE (Animal Research: Reporting of In Vivo Experiments) guidelines (Kilkenny et al., 2010). The protocol for this review was registered in the International Prospective Register of Systematic Reviews (Prospero) database and registered on the website https://www.crd.york.ac.uk/prospero/, through approved registry No. CRD42019121238.

\section{Literature Search}

The search was carried out through search strategies in the LILACS, PubMed, SciELO, and Scopus databases in 2019 and updated in March 2021. The terms used to compose the search in the databases were defined from consultations with $\mathrm{MeSH}$ and DeCS descriptors. Thus, the following search strategy was structured: "CITRUS" AND "Lipoproteins" OR "Cholesterol" OR "Epicholesterol" OR "Dyslipidemias" OR "Dyslipoproteinemia" OR "Hypercholesterolemia" OR "High Cholesterol Levels" OR "Hyperlipidemias" OR "Lipidemia," described in detail in Supplementary Table S1.

\section{Study Selection and Eligibility Criteria}

After excluding duplicate records, titles, abstracts, and full texts were independently analyzed by two researchers in order to determine the study's eligibility for inclusion in the review. The inclusion criteria were preclinical studies or randomized clinical trials that include the use of Citrus species to assess the effect on the lipid profile. In this review, were excluded reviews, case studies, case reports, and studies that did not assess the action on the lipid profile, which included the use of juices from Citrus species and their action on the lipid profile, or the association of Citrus species with another compound that could modify the lipid profile, as well as studies that used compounds isolated from Citrus species to target hyperlipidemia. To assess the agreement among researchers, the statistical test of the Kappa coefficient (K) was applied.

\section{Data Extraction and Risk of Bias Assessment}

Two independent reviewers extracted data from the included studies. The data from preclinical studies were as follows: Citrus species, type of extract and part of the plant, composition, 
hyperlipidemia induction model, evaluation methods, treatment, animal species, and results (all results that were in $\mathrm{mg} / \mathrm{dL}$ were converted to $\mathrm{mmol} / \mathrm{L}$ using the OnlineConversion.com electronic calculator according to the type of cholesterol). The data from clinical studies were as follows: Citrus species, type of extract and part of the plant, composition, study design/location, sample, criteria for inclusion and exclusion of participants, pathologies, treatment, and results (all results that were in $\mathrm{mmol} / \mathrm{L}$ were converted to $\mathrm{mg} / \mathrm{dL}$ using the OnlineConversion.com electronic calculator according to the type of cholesterol). All the outcomes of the experiments carried out in the articles were extracted for descriptive and inferential analyses.

Through ARRIVE, we apply the following: precise and concise description of the content of the article in the title, abstract, explanation of the methodological approach of the introduction, general and specific objectives, ethical nature of care and use of animals, study design regarding the number of animals per group, experimental procedures, information about animals such as sex, size, weight, and age, housing and breeding, sample size, statistical methods, description of results and their interpretation, and study funding.

All clinical studies included in this research were approved for methodological quality in the risk checklist of Cochrane randomized for controlled trials (Cochrane Training, 2019). Items such as generation of random sequence, concealment of allocation, certification of participants and professionals, as well as of evaluators, incomplete and selective outcomes, or whether the study presents any other problem or fraud were used. The studies considered as having the highest methodological quality were those related to randomization, blinding, and complete outcomes.

\section{Meta-Analysis}

The studies selected for the meta-analysis had the following outcomes analyzed: total cholesterol, LDL, HDL, and triglyceride levels, including the baseline and post-treatment data from both the control and treatment groups for both preclinical and clinical studies. In addition to the primary outcomes, to improve the understanding of the effects observed in preclinical studies, the studies were separated into the following subgroups: route of administration of the extract, type of animal, type of extract, and parts of the plant used.

For the quantitative analysis of the articles, the studies selected presented the value of the sample $n$, mean, deviation, or standard error for the serum levels of total cholesterol, LDL, HDL, and/or triglycerides of the treatment and control groups. All data were tabulated in Excel and later analyzed using the application of $\mathrm{R}$ software. The heterogeneity of the studies was measured using Cochran's Q test, using the $\mathrm{I}^{2}$ statistic, which was considered as heterogeneous when the $p$ value was less than 0.05 . The heterogeneity between the studies was defined using the $\mathrm{I}^{2}$ statistic, which was considered with an unimportant $\left(\mathrm{I}^{2}<\right.$ $25 \%)$, moderate $\left(25 \%<\mathrm{I}^{2}<75 \%\right)$, or high degree of heterogeneity $\left(\mathrm{I}^{2}>75 \%\right)$ (Higgins and Thompson, 2002). For heterogeneous studies $\left(\mathrm{I}^{2}>75 \%\right)$, the following subgroup analyses were performed: route of administration, type of animal, parts of the plant used in the extract, type of fruit, and type of extract. In addition, we performed a sensitivity analysis, sequentially removing the individual studies to determine whether any single study affected the overall effect estimate.

\section{RESULTS}

\section{Study Selection and Study Characteristics}

During the search process, 958 articles were obtained: 169 from PubMed, 762 from SciVerse Scopus, 12 from SciELO, and 15 from LILACS. After analyzing the titles, 598 duplicate articles were removed. After excluding the repeated articles, 360 titles were screened for analysis according to the inclusion criteria, from which 329 studies were excluded for not inducing hyperlipidemia in an animal model or for not having dyslipidemia installed in the case of clinical studies. In addition, studies with isolated compounds of the Citrus species or without evaluation of total cholesterol, LDL-C, HDL-C, or triglycerides were also excluded.

After this design, 31 articles remained, the full texts of which were analyzed, thus yielding 27 articles that were finally included in the qualitative synthesis (Figure 1; Tables 1-3). Of these, 22 studies were preclinical trials (Vinson et al., 1998; Bok et al., 1999; Terpstra et al., 2002; Zulkhairi et al., 2010; Ding et al., 2012; Kang et al., 2012; Raasmaja et al., 2013; Lu et al., 2013; Kim et al., 2013; Muhtadi et al., 2015; Dinesh and Hegde, 2016; Shin et al., 2016; Ashraf et al., 2017; Fayek et al., 2017; Chou et al., 2018; Feksa et al., 2018; Mir et al., 2019; Sato et al., 2019; Hase-Tamaru et al., 2019; Ling et al., 2020; Ke et al., 2020; Lee et al., 2020), 3 were exclusively clinical studies (Gorinstein et al., 2007; Toth et al., 2015; Cai et al., 2017) and 1 study contained preclinical and clinical protocols (Mollace et al., 2011) (Figure 1). For the quantitative synthesis, 25 articles (Vinson et al., 1998; Bok et al., 1999; Gorinstein et al., 2007; Zulkhairi et al., 2010; Mollace et al., 2011; Ding et al., 2012; Kang et al., 2012; Terpstra et al., 2012; Kim et al., 2013; Lu et al., 2013; Raasmaja et al., 2013; Muhtadi et al., 2015; Dinesh and Hegde, 2016; Shin et al., 2016; Ashraf et al., 2017; Cai et al., 2017; Fayek et al., 2017; Chou et al., 2018; Feksa et al., 2018; Hase-Tamaru et al., 2019; Mir et al., 2019; Sato et al., 2019; Ke et al., 2020; Lee et al., 2020; Ling et al., 2020) were selected. The level of agreement among the reviewers was 0.470 , being considered as moderate.

Tables 2 and 3 show the general characteristics and results of the preclinical studies, arranged in the chronological order of publication. Table 4 present the experimental conditions and results of clinical trials also arranged in the chronological order.

The selected articles were published between 1998 and 2020, with a predominance of the number of publications in 2013 ( $\mathrm{n}=$ 3), $2017(n=3), 2019(n=3)$, and $2020(n=3)$. These studies were conducted mainly in China $(\mathrm{n}=6 ; 23.0 \%)$ and Korea $(\mathrm{n}=5$; $19.2 \%)$ followed by Italy $(\mathrm{n}=2 ; 7.6 \%)$ and Japan $(\mathrm{n}=2 ; 7.6 \%)$, in addition to other countries in which only 1 study was found as described in Tables 1-3.

In the 26 selected articles, 15 different species of Citrus were studied in a dyslipidemia model: C. reticulata $(\mathrm{n}=4$; $15.3 \%)$, C. bergamia $(\mathrm{n}=3 ; 11.5 \%)$, C. sinensis $(\mathrm{n}=3 ; 13.6 \%)$, 


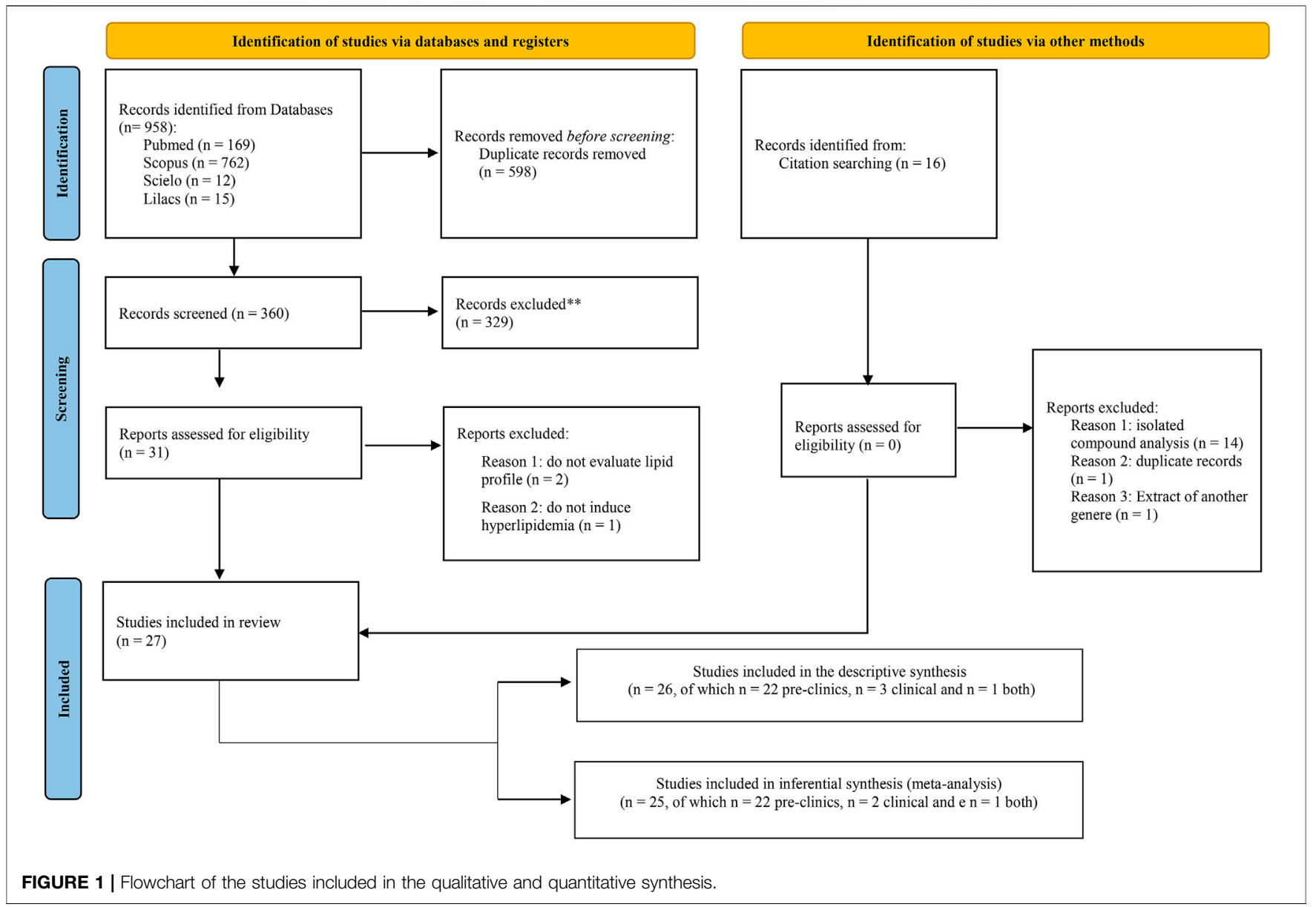

C. junos Tanaka ( $\mathrm{n}=2 ; 9.1 \%)$, C. grandis (L.) Osbeck also called C. maxima $(\mathrm{n}=3 ; 11.5 \%), C$. paradise also known as grapefruit $(\mathrm{n}=2 ; 7.6 \%)$, C. unshiu $(\mathrm{n}=2 ; 7.6 \%)$, C. sunki Hort. Ex Tanaka $(\mathrm{n}=1 ; 3.8 \%)$, C. aurantium $(\mathrm{n}=1 ; 3.8 \%)$, C. mitis $(\mathrm{n}=1 ; 3.8 \%)$, C. limon $(\mathrm{n}=1 ; 3.8 \%)$, C. aurantiifolia $(\mathrm{n}=1$; $3.8 \%)$, C. ichangensis $(\mathrm{n}=1 ; 3.8 \%)$, Poncirus trifoliata $\mathrm{x}$ Citrus sinensis $(\mathrm{n}=1 ; 3.8 \%)$, and $C$. changshan-huyou $(\mathrm{n}=1 ; 3.8 \%)$. Among the Citrus species used in the preclinical studies, there was a predominance of six hybrid species in eight studies, followed by three orange species in eight studies and three types of lemons in four publications and tangerine species in four articles. In the clinical studies, on the other hand, there is a predominance of orange-based bergamot products ( $C$. bergamia; $\mathrm{n}=3$ studies) and a study with supplements containing grapefruit (C. paradise).

From these species, hydroalcoholic extracts or organic fractions $(n=20 ; 86.9 \%)$, aqueous extract $(n=1 ; 4.3 \%)$, and processed fruits $(\mathrm{n}=3 ; 13.0 \%)$ were used, which were incorporated to the diet $(n=14 ; 60.8 \%)$ or administered orally by gavage $(n=9 ; 40.9 \%)$. In the clinical trials as a whole, supplementation with encapsulated dry extract was used or inclusion in the diet. In addition, 21 studies (80.7\%) evaluated the chemical composition of the extracts, with a predominance of compounds belonging to the class of flavonoids, such as naringin, hesperidin, neoeriocitrin, neohesperidin, nobiletin, tangeretin, and naringenin (Figure 2).

As observed in Table 1, the method of inducing hyperlipidemia in the preclinical studies was by cholesterolrich diet or cafeteria-type diet, conducted with rats $(\mathrm{n}=12$; $52.1 \%)$, mice $(n=8 ; 34.7 \%)$, and hamsters $(n=3 ; 13.0 \%)$. Among the randomized clinical trials (Table 3), the clinical conditions of the participants were in their entirety dyslipidemia $(n=4 ; 100 \%)$, associated or not with coronary disease $(n=1,25 \%)$, and hypertension and glucose intolerance $(n=1 ; 25 \%)$. In the preclinical and clinical studies, the outcomes evaluated were the levels of total cholesterol (TC, $\mathrm{n}=18 ; 100 \%$ ), HDL ( $\mathrm{n}$ $=14 ; 77.7 \%)$, LDL $(\mathrm{n}=12 ; 66.7 \%)$, VLDL $(\mathrm{n}=2 ; 13.3 \%)$, IDL $(\mathrm{n}=1 ; 5.5 \%)$, and triglycerides (TG, $\mathrm{n}=17 ; 94.4 \%)$.

From the analysis of the preclinical and clinical studies (Tables 2-4), it was found that the Citrus species were able to significantly alter the lipid profile in the $26(100 \%)$ studies, decreasing serum total cholesterol $(\mathrm{n}=25 ; 96.1 \%)$, LDL $(\mathrm{n}=14 ; 53.8 \%)$, triglycerides $(\mathrm{n}=17 ; 65.3 \%)$, and VLDL $(\mathrm{n}=2 ; 7.6 \%)$ and increasing $\mathrm{HDL}(\mathrm{n}=4 ; 15.3 \%)$. In the liver, Citrus also reduced TC and TG $(\mathrm{n}=6 ; 23.0 \%)$, lipid accumulation ( $\mathrm{n}=$ $5 ; 19.2 \%)$, and weight $(\mathrm{n}=2 ; 7.6 \%)$. These effects were accompanied by the maintenance $(\mathrm{n}=1 ; 3.8 \%)$ of glutamicoxaloacetic transaminase (GOT), glutamic-pyruvic transaminase (GPT), and alkaline phosphatase (ALP) serum levels or the 
TABLE 1 | Detailed description of the preclinical studies of the effect of Citrus extract on hyperlipidemia included in the systematic review.

\begin{tabular}{|c|c|c|c|c|c|c|}
\hline $\begin{array}{l}\text { References, } \\
\text { country }\end{array}$ & $\begin{array}{l}\text { Extract, plant } \\
\text { part, and } \\
\text { species }\end{array}$ & Composition & Model & $\begin{array}{l}\text { Evaluated } \\
\text { parameters }\end{array}$ & Treatment protocol & $\begin{array}{c}\text { Animal } \\
\text { (n/group) }\end{array}$ \\
\hline $\begin{array}{l}\text { Vinson et al., } \\
1998 \text { (Vinson } \\
\text { et al., 1998) }\end{array}$ & $\begin{array}{l}\text { Hydroalcoholic extract } \\
\text { of whole dried ripe } \\
\text { fruits C. aurantium }\end{array}$ & $\begin{array}{l}25.7 \% \text { ascorbic acid } \\
\text { 9.9\% flavonoids (quercetin, } \\
\text { hesperidin, naringenin, and } \\
\text { myricetin) }\end{array}$ & $\begin{array}{l}\text { Hamster fed on a high- } \\
\text { cholesterol diet }\end{array}$ & $\begin{array}{l}\text { LDL, VLDL } \\
\text { HDL, TC, TG, foam cell } \\
\text { injury }\end{array}$ & $\begin{array}{l}\text { Feed containing } 3 \% \text { of } \\
\text { the extract or } 4 \% \text { of } \\
\text { the extract associated } \\
\text { with ascorbic acid }\end{array}$ & $\begin{array}{l}\text { Male } \\
\text { Golden } \\
\text { Syrian }\end{array}$ \\
\hline EUA & & $\begin{array}{l}31.2 \% \text { protein } \\
3.2 \% \text { ash } \\
30 \% \text { carbohydrates }\end{array}$ & & $\begin{array}{l}\text { in the aorta artery } \\
\text { lipid peroxidation }\end{array}$ & $\begin{array}{l}(57 \mathrm{mmol} / \mathrm{kg} \text { diet }) \\
\text { daily, for } 4 \text { or } \\
10 \text { weeks }\end{array}$ & $\begin{array}{l}\text { Hamsters } \\
(\mathrm{n}=10)\end{array}$ \\
\hline Bok et al., & $\begin{array}{l}\text { Hydroalcoholic extract } \\
\text { of the peel C. reticulata }\end{array}$ & $2.7 \mathrm{~g}$ of protein & $\begin{array}{l}\text { Rats fed on a high- } \\
\text { cholesterol diet }\end{array}$ & $\begin{array}{l}\text { Plasmatic and hepatic } \\
\text { TC, TG, HDL, LDL }\end{array}$ & $\begin{array}{l}16.7 \mathrm{~g} / 100 \mathrm{~g} \text { of diet } \\
\text { for } 6 \text { weeks }\end{array}$ & Male \\
\hline $\begin{array}{l}1999 \text { (Bok et al., } \\
\text { 1999) }\end{array}$ & & $1.8 \mathrm{~g}$ of fat & & $\begin{array}{l}\mathrm{Al}^{\mathrm{a}} \text {, fecal neutral sterols, } \\
\mathrm{HMGR} \text {, and ACAT } \\
\text { activities in liver tissue }\end{array}$ & & $\begin{array}{l}\text { Sprague } \\
\text { Dawley rats } \\
(\mathrm{n}=10)\end{array}$ \\
\hline Korea & & $\begin{array}{l}1.0 \mathrm{~g} \text { of ash } \\
20 \mathrm{~g} \text { of fructose } \\
16.5 \mathrm{~g} \text { of glucose } \\
8.6 \mathrm{~g} \text { of sucrose } \\
0.6 \mathrm{~g} \text { of hesperidin } \\
0.03 \mathrm{~g} \text { of naringin and } 9.67 \mathrm{~g} \\
\text { of other sugars }\end{array}$ & & & & \\
\hline $\begin{array}{l}\text { Terpstra et al., } \\
2002 \text { (Terpstra } \\
\text { et al., 2002) }\end{array}$ & $\begin{array}{l}\text { Peels or waste stream } \\
\text { material of } C \text {. limon }\end{array}$ & - & $\begin{array}{l}\text { Hamster fed on a high- } \\
\text { cholesterol diet }\end{array}$ & BW, FI, and liver weight & $\begin{array}{l}\text { Diets containing } 3 \% \text { of } \\
\text { cellulose or lemon } \\
\text { peels or the waste } \\
\text { stream of the lemon } \\
\text { pectin extraction }\end{array}$ & Male hybrid \\
\hline Netherlands & & & & $\begin{array}{l}\text { TC of plasma and liver } \\
\text { Plasmatic TG, LDL, } \\
\text { HDL, VLDL } \\
\text { bile acids, and fecal } \\
\text { sterols }\end{array}$ & for 8 weeks & $\begin{array}{l}F_{1} B \text { Golden } \\
\text { Syrian } \\
\text { Hamster } \\
(n=14)\end{array}$ \\
\hline $\begin{array}{l}\text { Mollace et al., } \\
2011 \text { (Mollace } \\
\text { et al., 2011) }\end{array}$ & $\begin{array}{l}\text { Polyphenolic fraction } \\
\text { of } C \text {. bergamia Risso \& } \\
\text { Poiteau peeled-off }\end{array}$ & $\begin{array}{l}\text { Neoeriocitrin }(77,700 \mathrm{ppm}) \text {, } \\
\text { naringin }(63,011 \mathrm{ppm}) \\
\text { neohesperidin }\end{array}$ & $\begin{array}{l}\text { High-cholesterol diet- } \\
\text { induced hyperlipemia }\end{array}$ & BW, TC, LDL, HDL & $\begin{array}{l}10 \text { or } 20 \mathrm{mg} / \mathrm{kg} \\
\text { daily (p.o.) }\end{array}$ & Male \\
\hline Italy & fruits & $\begin{array}{l}\text { (72,056 ppm), melitidine } \\
\text { (15,606 ppm), and } \\
\text { brutieridine }(33,202 \mathrm{ppm})\end{array}$ & & $\begin{array}{l}\text { TG and glucose } \\
\text { Neutral sterols and fecal } \\
\text { bile acids }\end{array}$ & for 30 days & $\begin{array}{l}\text { Wistar } \\
\text { Rats } \\
(\mathrm{n}=10)\end{array}$ \\
\hline $\begin{array}{l}\text { Zulkhairi et al., } \\
\text { (Zulkhairi et al., } \\
\text { 2010) }\end{array}$ & $\begin{array}{l}\text { Aqueous extract ( } 5 \% \\
\text { and } 10 \%) \text { of dried } \\
\text { whole fruits C. mitis }\end{array}$ & Phenolic compounds & $\begin{array}{l}\text { Rats fed on a high- } \\
\text { cholesterol diet }\end{array}$ & $\begin{array}{l}\text { BW, TC, HDL, LDL, TG, } \\
\text { Al }^{b} \text {, sdLDL }\end{array}$ & $\begin{array}{l}5 \mathrm{mg} / \mathrm{kg} \text { of extract at } \\
5 \% \text { and } 10 \%\end{array}$ & Male \\
\hline Malaysia & & & & $\begin{array}{l}\text { Scavenging activity of } \\
\text { DPPH radicals, reducing } \\
\text { power, lipid } \\
\text { peroxidation (in vitro) }\end{array}$ & $\begin{array}{l}\text { daily (p.o.) } \\
\text { for } 10 \text { weeks }\end{array}$ & $\begin{array}{l}\text { Sprague } \\
\text { Dawley rats } \\
(\mathrm{n}=6)\end{array}$ \\
\hline Ding et al., & $\begin{array}{l}\text { Hydroalcoholic extract } \\
\text { of } C \text {. ichangensis peel }\end{array}$ & $\begin{array}{l}\text { Naringin, hesperidin, } \\
\text { poncirin, neoeriocitrin }\end{array}$ & High-fat diet-induced & BWG, FI & $\begin{array}{l}\text { Diet supplemented } \\
\text { with } 1 \% \text { of extract, for }\end{array}$ & Female \\
\hline $\begin{array}{l}2012 \text { (Ding et al., } \\
\text { 2012) } \\
\text { China }\end{array}$ & & $\begin{array}{l}\text { narirutin, neohesperidin, } \\
\text { naringenin, nobiletin, } \\
\text { and tangeretin }\end{array}$ & Obese & $\begin{array}{l}\text { TC, TG, LDL, HDL, and } \\
\text { glucose } \\
\text { Fecal and hepatic TC } \\
\text { and TG; size of EWAT; } \\
\text { mRNA expression of } \\
\text { PPAR } \gamma \text {, LXR, and them } \\
\text { target genes in liver } \\
\text { tissue }\end{array}$ & 8 weeks & $\begin{array}{l}\text { C57BL/6 } \\
\text { mice }(n=7)\end{array}$ \\
\hline Kang et al., & $\begin{array}{l}\text { Hydroalcoholic extract } \\
\text { of } C\end{array}$ & Tangeretin $(55.13 \mathrm{mg} / \mathrm{g})$ & High-fat diet-induced & $\mathrm{BWG}, \mathrm{FI}$ & $\begin{array}{l}150 \mathrm{mg} / \mathrm{kg} / \text { day of } \\
\text { extract (p.o.) }\end{array}$ & Male \\
\hline $\begin{array}{l}2012 \text { (Kang et al., } \\
\text { 2012) }\end{array}$ & sunki peel & Nobiletin (38.83 mg/g) & Obese & $\begin{array}{l}\text { TC, TG, GPT, GOT, and } \\
\text { LDH, EPAT weight, liver } \\
\text { fat; p-AMPK, p-ACC, }\end{array}$ & for 70 days & $\begin{array}{l}\text { C57BL/6 } \\
\text { mice } \\
(n=10)\end{array}$ \\
\hline
\end{tabular}


TABLE 1 | (Continued) Detailed description of the preclinical studies of the effect of Citrus extract on hyperlipidemia included in the systematic review.

\begin{tabular}{lccc}
$\begin{array}{l}\text { References, } \\
\text { country }\end{array}$ & $\begin{array}{c}\text { Extract, plant } \\
\text { part, and } \\
\text { species }\end{array}$ & Composition & $\begin{array}{c}\text { Model } \\
\text { Evaluated } \\
\text { parameters }\end{array}$ \\
\hline Korea & Hesperidin $(17.11 \mathrm{mg} / \mathrm{g})$ & In mature 3T3-L1 \\
& & adipocytes: LKB1, \\
& & AMPK, ACC, PKA, and \\
& HSL phosphorylation, & CPT-1a gene \\
& & expression, and glycerol \\
& & release
\end{tabular}

Sinensetin $(4.23 \mathrm{mg} / \mathrm{g})$

Raasmaja et al., Hydroalcoholic extract Naringin at $19 \%$

2013 (Raasmaja of C. grandis (L.)

et al., 2013) Osbeck whole fruits

Finland

Lu et al.,

2013 (Lu et al.

2013)

China

Kim et al.,

2013 (Kim et al., 2013)

Korea

Muhtadi et al., 2015 (Muhtadi

et al., 2015)

Indonesia

Dinesh and

Hegde, 2016

(Dinesh and

Hegde, 2016)

India

Shin et al.,

Hydroalcoholic extract -

of $C$. junos Tanaka

peel
High-fat diet-induced

Obese

Hydroalcoholic extract of Citrange (Poncirus trifoliata $\times$ C. sinensis) peel or flesh and seed

Neoeriocitrin $(14.5 \mathrm{mg} / \mathrm{g})$, naringin $(8.12 \mathrm{mg} / \mathrm{g})$, neohesperidin $(21.1 \mathrm{mg} / \mathrm{g})$, and poncirin $(14.1 \mathrm{mg} / \mathrm{g})$

Seed extract

Poncirin $(4.85 \mathrm{mg} / \mathrm{g})$

Neohesperidin $(1.87 \mathrm{mg} / \mathrm{g})$

Naringin $(0.87 \mathrm{mg} / \mathrm{g})$

Hydroalcoholic extract of $C$. junos Tanaka peel

Hesperidin (36.3 mg/100 g)

Naringin (11.6 mg/100 g)

Rutin $(2.7 \mathrm{mg} / 100 \mathrm{~g})$

Quercetin (1.7 mg/100 g) and tangeretin $(0.7 \mathrm{mg} /$ $100 \mathrm{~g})$

Hydroalcoholic extract of $C$. sinensis fruit peel

Hydroalcoholic extract of C. maxima leaves

Flavonoids, alkaloids, carbohydrates, glycosides, saponins, and tannins obese

High-fat diet-induced obese
2016 (Shin et al.,

2016)

Korea
High-fat diet-induced

hypercholesterolemia

Cafeteria diet and Olanzapine-induced obesity

Mice fed on a highcholesterol diet
High-fat diet-induced

induced by alloxan monohydrate BWG, FI

TC, TG, HDL, LDL, VLDL, GOT, GPT, glucose Liver weight and TG BWG, FI

TG, TC, HDL, GOT, GPT, ALP, histological analysis

of liver tissue
Diet supplemented with $1 \%$ and $5 \%$ of the extract

300,600, or
$1,200 \mathrm{mg} / \mathrm{kg}$ 1,200 mg/kg (p.o.) daily

for 12 weeks

Zucker

Rats

( $\mathrm{n}=10$ )

Female

Diet supplemented

with $1 \% \mathrm{w} / \mathrm{w}$ of peel

extract

or $1 \% \mathrm{w} / \mathrm{w}$ of flesh

C57BL/6

mice $(n=6)$

extract, daily

for 8 weeks

Diet supplemented with $1 \%$ and $5 \%$ of extract

for 9 weeks

C57BL/6 J mice $(\mathrm{n}=8)$

125, 250, and

$500 \mathrm{mg} / \mathrm{kg}$ (p.o.), daily

for 2 weeks

After 4-week diet

Wistar rats

( $\mathrm{n}=5$ )

200 and $400 \mathrm{mg} / \mathrm{kg} \quad$ Female

(p.o.), daily for

4 weeks

Wistar rats $(\mathrm{n}=6)$

for 10 weeks

C57BL/6 J mice $(\mathrm{n}=8)$ 
TABLE 1 | (Continued) Detailed description of the preclinical studies of the effect of Citrus extract on hyperlipidemia included in the systematic review.

\begin{tabular}{|c|c|c|c|c|c|c|}
\hline $\begin{array}{l}\text { References, } \\
\text { country }\end{array}$ & $\begin{array}{c}\text { Extract, plant } \\
\text { part, and } \\
\text { species }\end{array}$ & Composition & Model & $\begin{array}{c}\text { Evaluated } \\
\text { parameters }\end{array}$ & Treatment protocol & $\begin{array}{c}\text { Animal } \\
\text { (n/group) }\end{array}$ \\
\hline
\end{tabular}

Ashraf et al., Hydroalcoholic extract -

2017 (Ashraf of $C$. sinensis peel

et al., 2017)

Pakistan

Fayek et al.,

2017 (Fayek et al., 2017)

Egypt

Methanolic extract, hexanic extract, of $C$. reticulata (Mandarin), C. sinensis aqueous homogenate Mandarin (10.14\%) (sweet orange), C. paradise (white grapefruit), or $C$. aurantiifolia (lime) fruit peels

Chou et al., 2018 Methanolic extract of

(Chou et al., 2018)

China

Feksa et al., 2018 Hydroalcoholic extract (Feksa et al., 2018)

Brazil

Mir et al., 2019

(Mir et al., 2019)

Algeria

Sato et al., 2019

(Sato et al., 2019)

Japan

Tamaru et al.,

2019

(Hase-Tamaru

et al., 2019)

Japan

Lee et al., 2020

(Lee et al., 2020)

Korea

Ling et al., 2020

(Ling et al., 2020)
C. reticulata

of leaves of C. maxima

Hydroalcoholic extract

of C. latifolia

C. tumida peel powder
Lime (0.0045\%)

Lime (19.7\%)

Mandarin (9.14\%)

$0.07 \mathrm{mg} / \mathrm{g}$ )

Tangeretin $(1.67 \pm$

$0.05 \mathrm{mg} / \mathrm{g}$ ) compounds (2.7 g), ash (4.9 g), moisture, $40.9 \mathrm{~g}$ narirutin

C. unshiu: dried extract (CPEW) and lyophilized (CPEF)

synephrine

C. changshan-huyou neohesperidin

\section{Sweet orange (3.6\%)}

White grapefruit $(0.9 \%)$

Pectin (\%) in peel powder

Sweet orange (21.33\%)

While grapefruit (11.66\%)

Narirutin $(4.52 \pm 0.31 \mathrm{mg} / \mathrm{g}), \quad$ High-fat diet-induced

hesperidin (9.14 $\pm 0.32 \mathrm{mg}$ )

g), nobiletin (2.54 \pm

Gallic acid, catechin, caffeic

acid, epicatechin, rutin and

isoquercetin, and the major

were caffeic acid $(3.71 \mathrm{mg} / \mathrm{g})$ and catechin $(3.65 \mathrm{mg} / \mathrm{g}$

Calorie (275 kcal), moisture $(2.9 \mathrm{~g})$, protein $(7.4 \mathrm{~g})$, fat carbohydrate $(82.1 \mathrm{~g})$, sugar (28.4 g), fiber (53.7 g), galacturonic acid (12.2 g), and sodium (4.3 mg) $76.1 \mathrm{~g}$ carbohydrate, $7.6 \mathrm{~g}$ crude protein, $0.7 \mathrm{~g}$ crude fat, $2.7 \mathrm{~g}$ ash, $12.9 \mathrm{~g}$ total fiber, $6.6 \mathrm{~g}$ total pectin, $14.4 \mathrm{~g}$ hesperidin, and $3.0 \mathrm{~g}$

Hesperidin, narirutin, and High-fat diet

\section{obese}

Hypercholesterolemia induced by diet rich in cholesterol

High-fat diet

High-fat diet

\section{Naringin, narirutin, and High-fat diet}

Rats fed on high-glucose or cholesterol-rich diet

Hypercholesterolemia induced by diet rich in

TC

TG and glucose

BWG, FI glucose, insulin cholesterol and bile salts

Expression of PPARa, FAS, and HMGR in liver tissue

Lipid accumulation and expression of $p$-AMPK, p-ACC, PPARa, CPT-1, and HMGR in HepG2

cells

High-fat diet and fructose

triglyceride, total
TG, TC, LDL, HDL, cholesterol, LDL, HDL, glucose, urea, creatinine,

triglyceride, and total cholesterol

AST, ALT, triglyceride, total cholesterol, HDL$\mathrm{C}$, creatinine, albumin, calcium, and LDH

$\begin{array}{ll}\begin{array}{l}\text { Diet supplemented } \\ \text { with } 10 \% \text { Citrus peel } \\ \text { powder (functional) }\end{array} & \begin{array}{l}\text { Male } \\ \text { Sprague }\end{array} \\ \begin{array}{l}\text { and } 5 \% \text { peel extract } \\ \text { (nutraceutical), for } \\ 8 \text { weeks }\end{array} & \begin{array}{l}\text { Dawley rats } \\ (\mathrm{n}=6)\end{array} \\ \begin{array}{l}0.1 \mathrm{ml} \text { of the } \\ \text { corresponding extract } \\ \text { (p.o.) for } 8 \text { weeks }\end{array} & \text { Male } \\ & \begin{array}{l}\text { Wistar rats } \\ (\mathrm{n}=6)\end{array}\end{array}$

$1 \%$ of the corresponding extract for 11 weeks

C57BL/6 J mice $(\mathrm{n}=8)$ Male

Wistar rats

( $\mathrm{n}=$

$1 \%$ of the corresponding extract for 4 weeks

Wistar rats

C. tumida peel powder 5\% (w/w)

C57BL/6 J mice $(\mathrm{n}=8)$

Total cholesterol, triglycerides, free fatty acids, glucose, insulin, and leptin

$2.5 \%$

Sprague Dawley (SD) rats $(\mathrm{n}=7)$

$5.0 \%$, or $10.0 \%$

AST, ALT, triglyceride, total cholesterol, and LDL-C

$\begin{array}{ll}\text { CPEW: } 50 \mathrm{mg} / \mathrm{kg} ; & \text { Male } \\ 100 \mathrm{mg} / \mathrm{kg} & \\ \text { CPEF: } 50 \mathrm{mg} / \mathrm{kg} ; & \text { SD rats } \\ 100 \mathrm{mg} / \mathrm{kg} & (\mathrm{n}=8) \\ \text { PTFC: } 25 \mathrm{mg} / \mathrm{kg} ; & \\ 50 \mathrm{mg} / \mathrm{kg} ; 100 \mathrm{mg} / \mathrm{kg} & \\ \text { (Continued on following page) }\end{array}$


TABLE 1 | (Continued) Detailed description of the preclinical studies of the effect of Citrus extract on hyperlipidemia included in the systematic review.

\begin{tabular}{|c|c|c|c|c|c|c|}
\hline $\begin{array}{l}\text { References, } \\
\text { country }\end{array}$ & $\begin{array}{l}\text { Extract, plant } \\
\text { part, and } \\
\text { species }\end{array}$ & Composition & Model & $\begin{array}{c}\text { Evaluated } \\
\text { parameters }\end{array}$ & Treatment protocol & $\begin{array}{c}\text { Animal } \\
\text { (n/group) }\end{array}$ \\
\hline China & & & & $\begin{array}{l}\text { AST, ALT, triglyceride, } \\
\text { total cholesterol, LDL-C, } \\
\text { and HDL-C }\end{array}$ & & $\begin{array}{l}\text { Golden } \\
\text { hamsters } \\
(n=12)\end{array}$ \\
\hline $\begin{array}{l}\text { Ke et al., } 2020 \\
\text { (Ke et al., 2020) } \\
\text { China }\end{array}$ & C. reticulata Blanco & $\begin{array}{l}\text { Nobiletin }(98.34 \mathrm{mg} / \mathrm{g}) \text {, } \\
\text { heptamethoxyflavone } \\
(44.26 \mathrm{mg} / \mathrm{g}) \text {, tangeretin } \\
(26.20 \mathrm{mg} / \mathrm{g}) \text {, and } \\
\text { isosinensetin }(26.14 \mathrm{mg} / \mathrm{g})\end{array}$ & High-fat diet & $\begin{array}{l}\text { Triglyceride, total } \\
\text { cholesterol, LDL-C, and } \\
\text { HDL-C }\end{array}$ & 0.2 and $0.5 \%$ JZE & $\begin{array}{l}\text { C57BL/6 J } \\
\text { mice }(n=8)\end{array}$ \\
\hline
\end{tabular}

${ }^{\text {glutamic }}$ p.o., intragastric gavage; TC, total cholesterol; TG, triglycerides; LDL, low-density lipoprotein; HDL, high-density lipoprotein; VLDL, very low-density lipoprotein; LDH, lactate dehydrogenase; GOT, -oxaloacetic transaminase; GPT, glutamic-pyruvic transaminase; EWAT, epididymal white adipose tissue; PPAR $y$, peroxisome proliferator-activated receptor $\gamma$; FAS, fatty acid synthase; ACO, acyl-CoA oxidase; $L X R \alpha$, liver X receptor $\alpha$; $L X R \beta$, liver X receptor $\beta ; A M P K$, AMP-activated protein kinase; ACC, acetyl-CoA carboxylase; PKA, cAMPdependent protein kinase; HSL, hormone-sensitive lipase. GLP-1, glucagon-like peptide-1; PYY, pancreatic peptide YY; BWG, body weight gain; Fl, food intake; ipGTT, intraperitoneal glucose tolerance test; ALP, alkaline phosphatase; FAS, fatty acid synthase receptor; CPT-1, carnitine palmitoyl transferase-1; HMGR, 3-hydroxy-3-methylglutaryl-coenzyme A reductase; EPAT, epididymal and perirenal adipose tissue; EAT, epididymal adipose tissue.

${ }^{a}$ The duration of the experiment is not explicitly informed in the article. Al, atherogenic index.

b[(TC-HDL)/HDL]

${ }^{c}(L D L / H D L) ; s d L D L$, small dense $L D L$, particle size.

${ }^{d}(T G / H D L)$.

reduction of GOT, GPT ( $\mathrm{n}=2 ; 7.6 \%)$, and lactate dehydrogenase $(\mathrm{LDH})(\mathrm{n}=1 ; 3.8 \%)$.

In addition, some Citrus products also reduced body weight gain (BWG; $\mathrm{n}=7 ; 26.9 \%$ ), food intake (FI; $\mathrm{n}=1 ; 3.8 \%$ ), and lipid accumulation in adipose tissue or cells $(n=3 ; 11.5 \%)$. In human, a study also demonstrated their effect on the reduction of waist circumference (WC), waist-to-hip ratio (WHR), and body mass index (BMI). Taken together, these effects can reduce the risk of atherosclerosis as shown in three studies (16.6\%). However, its effects on the lipid excretion are still controversial, since two studies $(11.0 \%)$ demonstrate increased excretion, two studies (11.0\%) did not identify changes, and only one study $(5.5 \%)$ found a reduction in excretion (Table 3 ). In parallel, some authors investigated the effect of Citrus-based products on glucose and their effects on blood glucose reduction $(n=8$; $44.4 \%)$, insulin increase $(n=2 ; 11.0 \%)$, and glucose uptake in the cell ( $\mathrm{n}=1 ; 5.5 \%)$.

In addition, several targets involved in the energy and nutrient metabolism have been studied. As can be seen in Table 3, some species of Citrus demonstrated effects on peroxisome proliferator-activated receptor $\gamma(\operatorname{PPAR} \gamma)$ and peroxisome proliferator-activated receptor a (PPARa), downmodulating fatty acid synthase (FAS), acyl-CoA oxidase (ACO), uncoupling protein 2 (UCP2), and adipocyte fatty-acidbinding protein ( $\mathrm{aP2}$ ), besides upregulating CD36 and acetylCoA carboxylase (ACC). They can also act on liver $\mathrm{X}$ receptor (LXR), reducing lipoprotein lipase (LPL), apolipoprotein E (ApoE), and cholesterol 7a-hydroxylase (CYP7A1) and increasing ATP-binding cassette transporter G1 (ABCG1) and ATP-binding cassette transporter A1 (ABCA1).

The adiponectin signaling pathway also can be involved in the lipid control. In fact, some Citrus products were able to increase adiponectin; stimulate the phosphorylation of LKB1, AMPactivated protein kinase (AMPK), ACC, and carnitine palmitoyl transferase-1 (CPT-1); and reduce HMGR and ACAT activities. Their effects on lipolysis were also observed by the upmodulation of cAMP-dependent protein kinase (PKA) and hormone-sensitive lipase (HSL), with increase in glycerol. Besides adiponectin, Citrus seems to act reducing other adipocytokines, as leptin and resistin, which regulate the appetite and glucose metabolism and have been associated with insulin resistance. Their effects were also observed in the hormones involved with satiety and hunger control, as leptin, glucagon-like peptide-1 (GLP-1), and ghrelin. Finally, the antioxidant potential of Citrus has also been demonstrated, which can offer benefits in reducing lipid oxidation and in the development of atheromatous plaques.

\section{Methodological Quality/Risk of Bias}

The 23 preclinical studies, using the criteria provided by the ARRIVE guidelines, were analyzed for methodological quality. The studies showed a percentage of adequacy varying between 50 and $92 \%(83.82 \pm 10.77 \%)$, with a greater weakness in the quality of the methodological description of the studies (Supplementary Table S2).

As for the clinical studies included in this research and evaluated by the Cochrane list (Figure 3), all of them had blinding outcome evaluators and incomplete outcomes. In addition, $50 \%$ of the articles presented low risk of uncertain bias regarding the criteria of generating a random sequence, concealment of allocation, blinding of the participants, reporting of the selective outcome, and other sources of bias (conflict of interest, based on the source of funding for the study and method of determination of the sample size).

\section{Meta-Analysis}

For the meta-analysis, the preclinical studies measured the level of total cholesterol $\left[\mathrm{n}=23 ; 100 \% ; \mathrm{I}^{2}=99.1 \%(98.9 \% ; 99.2 \%)\right]$, triglycerides $\left[\mathrm{n}=20 ; 87 \% ; \mathrm{I}^{2}=99.4 \%(99.3 \% ; 99.5 \%)\right], \mathrm{LDL}[\mathrm{n}=$ $\left.12 ; 52.2 \% ; \mathrm{I}^{2}=99.1 \%(98.9 \% ; 99.3 \%)\right]$, and HDL $\left[\mathrm{n}=14 ; 60.9 \% ; \mathrm{I}^{2}\right.$ $=93.4 \%(90.6 \% ; 95.4 \%)]$. As for the clinical studies, three clinical trials with 92, 98, and 237 participants were included in the 
TABLE 2 | Outcomes of the preclinical studies included in this systematic review.

\section{Reference}

Vinson et al., (Vinson et al., 1998)

Bok et al. (Bok et al., 1999)

Baseline

6 weeks: TC: 2.44 ; HDL: 0.61

TG: 1.22

Terpstra et al. (Terpstra et al., Baseline:

2002)

Mollace et al. (Mollace et al., 2011)

Zulkhairi et al. (Zulkhairi et al.

2010)

Kang et al. (Kang et al., 2012) Baseline:

70 days

TC: 3.81 ; TG: 0.94

Raasmaja et al. (Raasmaja et al., 2013)

Lu et al. (Lu et al., 2013)

8 weeks (lemon peel): TC: 3.51

8 weeks (waste stream): TC: 3.44

Baseline:

30 days (10 mg): TC: 5.95; LDL: 4.49; HDL: 0.58; TG: 2.75

30 days (20 mg): TC: 5.00; LDL: 3.90;

HDL: 0.65; TG: 2.74

Baseline (5\%)

TC: 1.73; LDL: 0.45; HDL: 1.34;

TG: 0.76

Baseline (10\%)

TC: 1.68; LDL: 0.49; HDL: 1.27 ; TG: 0.74

4 weeks (5\%)

TC: 1.28; LDL: 0.27; HDL: 1.39;

TG: 0.63

4 weeks (10\%)

TC: 1.06; LDL: 0.23; HDL: 1.54;

TG: 0.53

Ding et al. (Ding et al., 2012) Baseline:

8 weeks

TC: 2.27; LDL: 0.35; HDL: 2.32;

TG: 0.70

Baseline $(300 \mathrm{mg} / \mathrm{kg})$

TC: 3.72; HDL: 1.42; TG: 8.34

Baseline $(600 \mathrm{mg} / \mathrm{kg})$

TC: 3.13; HDL: 1.70; TG: 6.27

Baseline $(1,200 \mathrm{mg} / \mathrm{kg})$

TC: 3.59; HDL: 1.53; TG: 8.11

12 weeks (300 mg/kg)

TC: 4.23; HDL: 0.44; TG: 16.68

12 weeks $(600 \mathrm{mg} / \mathrm{kg})$

TC: 3.62; HDL: 0.80; TG: 12.57

12 weeks $(1,200 \mathrm{mg} / \mathrm{kg})$

TC: 4.36; HDL: 0.80; TG: 17.42

Baseline

\section{Control group (mmol/L)}

\section{Summary of results}

Baseline: TC: 10.3; HDL: 2.84; $\downarrow$ TC and TG

TG: 41.6

10 weeks: TC: 15.1 ; HDL: 1.48; $\downarrow$ lipid peroxidation

TG: 55.9

$\downarrow$ atherosclerosis signals ( $\downarrow$ area and density of foam cells), without changing BW

Baseline:

6 weeks: TC: 3.8; HDL: 0.57; $\downarrow$ plasma TC

TG: 1.12

$\downarrow$ hepatic TC and TG, without changing HDL, TG, and LDL plasmatic

$\downarrow$ Al and cholesterol excretion

$\downarrow$ HMGR and ACAT activities

Baseline:

$\downarrow$ plasma and liver TC, $\downarrow$ VLDL + LDL being more effective in $\downarrow V L D L$, without changing HDL, $\uparrow$ excretion of fecal neutral sterols and bile acids

8 weeks (cellulose): TC: 4.21

without changing $\mathrm{BW}, \mathrm{FI}$, and liver weight

Baseline:

30 days: TC: 8.19; LDL 6.04

$\downarrow T C$, LDL, and TG, without changing BW, HDL and glucose $\uparrow$ fecal neutral sterols and bile acids
Baseline: TC: 1.75; LDL: 0.45; $\quad \downarrow$ TC, LDL, TG

HDL: 0.85; TG: 0.54

4 weeks

$\uparrow H D L$

TC: 2.13; LDL: 0.93; HDL: 0.89; $\quad \downarrow A l$ and sdLDL

TG: 0.79

Antioxidant activity, without changing BW

Baseline:

8 weeks

TC: 2.65; LDL: 0.46; HDL: 1.95;

TG: 0.70

Baseline:

70 days: TC: 4.63 ; TG: 1.56

Baseline

TC: 3.56; HDL: 1.67; TG: 7.31

12 weeks

TC: 4.13; HDL: 0.52; TG: 15.76 $\downarrow B W G$

$\downarrow T C$ and LDL plasmatic

$\downarrow$ hepatic TC, TG, glucose, and adipocyte size, without changing

Plasmatic Fl, HDL, and TG and

fecal TC and TG

$\downarrow$ expression of PPAR $\gamma$ ( $\downarrow F A S, A C O$, and UCP2 and $\uparrow$ CD36) $\downarrow$ $L X R \alpha$ and $\beta$ ( $\downarrow$ ApoE, CYP7A1, LPL, and $\uparrow A B C A 1)$

$\downarrow B W G$ without changing in $\mathrm{Fl}$

$\downarrow$ TC, TG, LDH, GOT, and GPT

$\downarrow$ weight and cell size of EPAT

$\downarrow$ liver fat

$\uparrow \mathrm{p}-\mathrm{AMPK}, \mathrm{p}-\mathrm{ACC}, \mathrm{p}-\mathrm{LKB} 1$, and adiponectin

$\uparrow$ glycerol release

$\uparrow \mathrm{p}-\mathrm{PKA}$ and $\mathrm{p}-\mathrm{HSL}$

Tendency to $\downarrow$ TC, glucose, and TG and $\uparrow \mathrm{HDL}$

$\downarrow$ GLP-1 and reversing the $\downarrow$ of ghrelin, without changing

BWG, FI

PYY, leptin, insulin, and amylin 
TABLE 2 | (Continued) Outcomes of the preclinical studies included in this systematic review.

\begin{tabular}{|c|c|c|c|}
\hline Reference & Experimental group (mmol/L) & Control group (mmol/L) & Summary of results \\
\hline & 8 weeks (peel) & 8 weeks & Improves glucose tolerance and insulin resistance \\
\hline & $\begin{array}{l}\text { TC: } 2.30 ; \text { LDL: 0.36; HDL: } 2.00 \\
\text { TG: } 0.70\end{array}$ & $\begin{array}{l}\text { TC: } 2.64 ; \text { LDL: } 0.41 ; \text { HDL: } 1.97 \\
\text { TG: } 0.70\end{array}$ & $\downarrow$ serum glucose, TC, and LDL \\
\hline & 8 weeks (seed) & & $\begin{array}{l}\downarrow \text { hepatic TC and TG, without changing FI, serum HDL, and } \\
\text { fecal TC and TG }\end{array}$ \\
\hline & $\begin{array}{l}\text { TC: } 2.43 ; \text { LDL: } 0.41 ; \text { HDL: } 1.87 ; \\
\text { TG: } 0.74\end{array}$ & & $\downarrow$ PPAR $\gamma$ ( $\downarrow$ ap2, FAS); $\downarrow$ LXR $\beta$ ( $\downarrow$ LPL and ApoE and $\uparrow$ ABCG1) \\
\hline & & & $\downarrow$ lipid accumulation in liver tissue \\
\hline \multirow[t]{5}{*}{ Kim et al. (Kim et al., 2013) } & Baseline & Baseline: & $\downarrow$ BWG, glucose, TG, TC, insulin, leptin, and resistin \\
\hline & 9 weeks (1\%) & 9 weeks & $\uparrow$ glucose uptake \\
\hline & TC: $2.00 ;$ TG: 0.85 & TC: $2.37 ;$ TG: 0.88 & $\downarrow$ liver tissue fat \\
\hline & 9 weeks $(5 \%)$ & & $\uparrow$ PPAR $\gamma$ and AMPK, without changing FI, GOT, and GPT \\
\hline & TC: 1.91; TG: 0.76 & & \\
\hline \multirow{6}{*}{$\begin{array}{l}\text { Muhtadi et al. (Muhtadi et al., } \\
\text { 2015) }\end{array}$} & Baseline (125 mg/kg): TC: 4.31 & Baseline: TC: 3.77 & $\downarrow \mathrm{TC}$ and glucose \\
\hline & Baseline (250 mg/kg): TC: 5.08 & 2 weeks: TC: 3.27 & \\
\hline & Baseline $500(\mathrm{mg} / \mathrm{kg}):$ TC: 4.87 & & \\
\hline & 2 weeks (125 mg/kg): TC: 1.88 & & \\
\hline & 2 weeks (250 mg/kg): TC: 2.13 & & \\
\hline & 2 weeks (500 mg/kg): TC: 2.02 & & \\
\hline \multirow{7}{*}{$\begin{array}{l}\text { Dinesh and Hegde (Dinesh } \\
\text { and Hegde, 2016) }\end{array}$} & Baseline & Baseline: & $\downarrow B W G$ and $\mathrm{Fl}$ \\
\hline & 4 weeks (200 mg/kg) & 4 weeks & $\downarrow \mathrm{TC}, \mathrm{TG}, \mathrm{LDL}$, and VLDL \\
\hline & $\begin{array}{l}\text { TC: } 79.76 \text {; LDL: } 54.31 \text {; HDL: 40.68; } \\
\text { TG: } 104.3\end{array}$ & $\begin{array}{l}\text { TC: } 88.75 \text {; LDL: } 74.71 \text {; HDL: } \\
\text { 35.11; TG: } 130.0\end{array}$ & $\uparrow \mathrm{HDL}$ \\
\hline & 4 weeks $(400 \mathrm{mg} / \mathrm{kg})$ & & $\downarrow$ GOT and GPT \\
\hline & TC: 75.77; LDL: 51.75; HDL: 43.22; & & $\downarrow$ liver weight and TG \\
\hline & TG: 98.05 & & \\
\hline & & & $\downarrow$ glucose \\
\hline \multirow[t]{6}{*}{ Shin et al. (Shin et al., 2016) } & Baseline: & Baseline: & $\downarrow B W G$ \\
\hline & 10 weeks $(1 \%)$ & 10 weeks & $\downarrow$ TC, LDL, GOT, GPT, ALP, without changing FI, HDL \\
\hline & TC: 2.89; LDL: 1.81; HDL: 0.87 & TC: 4.03; LDL: 3.03; HDL: 0.80 & $\downarrow$ liver fat content and weight \\
\hline & 10 weeks $(5 \%)$ & & $\uparrow \mathrm{p}-\mathrm{AMPK}, \mathrm{p}-\mathrm{ACC}, \mathrm{PPARa}$, and CPT-1 expression \\
\hline & TC: 2.96; LDL: 1.80; HDL: 0.80 & & $\downarrow F A S$ and HMGR expression \\
\hline & & & $\downarrow$ lipid accumulation \\
\hline \multirow{9}{*}{$\begin{array}{l}\text { Ashraf et al. (Ashraf et al., } \\
\text { 2017) }\end{array}$} & Baseline (powder) & Baseline & Tendency to \\
\hline & $\begin{array}{l}\text { TC: } 3.34 ; \text { HDL: 1.19; LDL: } 1.67 ; \\
\text { TRI: } 1.07\end{array}$ & $\begin{array}{l}\text { TC: } 3.30 ; \text { HDL: 1.17; LDL: 1.63; } \\
\text { TRI: } 1.04\end{array}$ & $\downarrow \mathrm{BWG}$ and $\mathrm{FI}$ \\
\hline & Baseline (extract) & 8 weeks & $\downarrow \mathrm{TG}, \mathrm{TC}$, and LDL \\
\hline & $\begin{array}{l}\text { TC: } 3.32 ; \text { HDL: 1.21; LDL: } 1.62 ; \\
\text { TRI: } 1.05\end{array}$ & $\begin{array}{l}\text { TC: } 3.81 \text {; HDL: } 1.17 ; \text { LDL: } 1.85 \\
\text { TRI: } 1.16\end{array}$ & $\uparrow \mathrm{HDL}$ \\
\hline & 8 weeks (powder) & & $\downarrow$ glucose and $\uparrow$ insulin \\
\hline & TC: 3.14; HDL: 1.21; LDL: 1.52; & & \\
\hline & TRI: 1.01 & & \\
\hline & 8 weeks (extract) & & \\
\hline & $\begin{array}{l}\text { TC: } 3.03 ; \text { HDL: 1.24; LDL: } 1.44 ; \\
\text { TRI: } 0.97\end{array}$ & & \\
\hline \multirow{9}{*}{$\begin{array}{l}\text { Fayek et al. (Fayek et al., } \\
\text { 2017) }\end{array}$} & Baseline: & Baseline: & Tendency to $\downarrow$ TC \\
\hline & Tangerine (alcoholic extract) & Diet & $\downarrow \mathrm{TG}$ and glucose \\
\hline & TC: $2.00 ;$ TG: 0.78 & TC: 3.92; TG: 2.66 & \\
\hline & Orange (alcoholic extract) & & \\
\hline & TC: 3.25; TG: 0.94 & & \\
\hline & Hybrid (alcoholic extract) & & \\
\hline & TC: 3.95; TG: 0.85 & & \\
\hline & Lime (alcoholic extract) & & \\
\hline & TC: $5.47 ;$ TG: 0.51 & & \\
\hline \multirow[t]{3}{*}{ Chou et al. (Chou et al., 2018) } & Baseline: & Baseline: & Tendency to $\downarrow$ TC \\
\hline & 11 weeks (1\%) & 11 weeks (diet) & $\downarrow \mathrm{TG}$ and insulin resistance \\
\hline & TC: $3.85 ;$ TG: 0.44 & TC: 4.68; TG: 0.85 & \\
\hline \multirow{3}{*}{$\begin{array}{l}\text { Feksa et al. (Feksa et al., } \\
\text { 2018) }\end{array}$} & Baseline & Baseline: & Tendency to \\
\hline & 45 days $(50$ mg/kg) & $\begin{array}{l}45 \text { days (diet): TC: } 3.34 ; \text { TG: } \\
\text { 3.38; HDL: } 0.47 \text {; LDL: } 1.23\end{array}$ & $\downarrow \mathrm{TG}, \mathrm{TC}$, and LDL \\
\hline & $\begin{array}{l}\text { TC: 2.12; TG: 2.84; HDL: 0.34; } \\
\text { LDL: } 0.61\end{array}$ & & \\
\hline \multirow[t]{2}{*}{ Mir et al. (Mir et al., 2019) } & Baseline & Baseline: & Tendency to \\
\hline & 4 weeks (1\%) & 4 weeks (diet) & $\downarrow \mathrm{TG}$ and TC \\
\hline
\end{tabular}


TABLE 2 | (Continued) Outcomes of the preclinical studies included in this systematic review.

\begin{tabular}{|c|c|c|c|}
\hline Reference & Experimental group (mmol/L) & Control group (mmol/L) & Summary of results \\
\hline & TC: 3.8; TG: 0.9 & TC: 5.9; TG: 1.8 & \\
\hline \multirow[t]{3}{*}{ Sato et al. (Sato et al., 2019) } & Baseline: & Baseline: & Tendency to \\
\hline & 4 weeks (5\%) & 4 weeks (diet) & $\downarrow$ TG and TC \\
\hline & TC: 3.31; TG: 0.28; HDL: 2.06 & TC: 4.39; TG: 0.41; HDL: 2.42 & \\
\hline \multirow{7}{*}{$\begin{array}{l}\text { Tamaru et al. (Hase-Tamaru } \\
\text { et al., 2019) }\end{array}$} & Baseline: & Baseline: & Tendency to \\
\hline & 4 weeks (2.5\%) & 4 weeks (diet) & $\downarrow \mathrm{TG}$ and TC \\
\hline & TC: 2.01; TG: 1.67 & TC: 2.27 TG: 2.00 & $\downarrow$ free fatty acids, glucose, insulin, and leptin \\
\hline & 4 weeks $(5 \%)$ & & $\downarrow$ FAS, G6PDH in cytosol, and PAP in microsome \\
\hline & TC: $2.22 ;$ TG: 1.63 & & \\
\hline & 4 weeks $(10 \%)$ & & \\
\hline & TC: $1.72 ;$ TG: 2.74 & & \\
\hline \multirow[t]{7}{*}{ Lee et al. (Lee et al., 2020) } & Baseline & Baseline: & Tendency to \\
\hline & $\begin{array}{l}8 \text { weeks (CPEW } 50 \text { mg/kg): TC: } 4.00 \text {; } \\
\text { TG: 2.89; LDL: } 2.58\end{array}$ & $\begin{array}{l}8 \text { weeks (diet): TC: } 4.00 ; \text { TG: } \\
\text { 2.89; LDL: } 2.58\end{array}$ & $\downarrow$ TG and TC \\
\hline & 8 weeks (CPEW 100 mg/kg): TC: 3.54; & & \\
\hline & TG: 2.52; LDL: 2.27 & & \\
\hline & 8 weeks (CPEF 50 mg/kg): TC: 4.08; & & \\
\hline & TG: 2.79; LDL: 2.56 & & \\
\hline & $\begin{array}{l}8 \text { weeks (CPEF } 100 \text { mg/kg): TC: 3.64; } \\
\text { TG: 2.59; LDL: } 2.37\end{array}$ & & \\
\hline \multirow[t]{5}{*}{ Ling et al. (Ling et al., 2020) } & Baseline & Baseline: & Tendency to \\
\hline & $\begin{array}{l}4 \text { weeks (25 mg/kg): TC: } 32.00 ; \text { TG: } \\
\text { 10.20; HDL: 2.30; LDL: } 11.41\end{array}$ & 4 weeks (diet) & $\downarrow \mathrm{TG}, \mathrm{TC}$, and LDL-C \\
\hline & 4 weeks (50 mg/kg): TC: 22.30; TG: & TC: 41.59; TG: 11.15; HDL: & \\
\hline & 5.30; HDL: 2.83; LDL: 9.83 & 4.95; LDL: 11.80 & \\
\hline & $\begin{array}{l}4 \text { weeks (100 mg/kg): TC: } 21.70 ; \text { TG: } \\
\text { 5.30; HDL: 2.65; LDL: } 8.67\end{array}$ & & \\
\hline \multirow[t]{3}{*}{ Ke et al. (Ke et al., 2020) } & Baseline & Baseline: & Tendency to \\
\hline & $\begin{array}{l}4 \text { weeks (0.2\%): TC: } 5.69 ; \text { TG: 0.28; } \\
\text { HDL: } 4.10 \text {; LDL: } 1.01\end{array}$ & 4 weeks (diet) & $\downarrow \mathrm{TG}, \mathrm{TC}$, and LDL-C \\
\hline & $\begin{array}{l}4 \text { weeks (0.5\%): TC: } 5.04 ; \text { TG: 0.28; } \\
\text { HDL: 3.84; LDL: } 0.81\end{array}$ & $\begin{array}{l}\text { TC: } 5.62 ; \text { TG: 0.41; HDL: 4.20; } \\
\text { LDL: } 1.20\end{array}$ & \\
\hline
\end{tabular}

TC, total cholesterol; TG, triglycerides; LDL, low-density lipoprotein; HDL, high-density lipoprotein; VLDL, very low-density lipoprotein; BW, body weight; HMGR, 3-hydroxy-3methylglutaryl-coenzyme A reductase; ACAT, acyl-COA cholesterol acyltransferase; Al, atherogenic index; FI, food intake; BWG, body weight gain; PPARy, peroxisome proliferatoractivated receptor $\gamma$; FAS, fatty acid synthase; ACO, acyl-CoA oxidase; UCP2, uncoupling protein 2; CD36, cluster of differentiation 36; LXR, liver X receptor; ApoE, apolipoprotein E; CYP7A1, cholesterol 7 $\alpha$-hydroxylase; LPL, reducing lipoprotein lipase; ABCA1, ATP-binding cassette transporter A1; $L D H$, lactate dehydrogenase; GPT, glutamic-pyruvic transaminase; GOT, glutamic-oxaloacetic transaminase; AMPK, AMP-activated protein kinase; ACC, acetyl-CoA carboxylase; PKA; AMP-dependent protein kinase; HSL, hormone-sensitive lipase; PYY, pancreatic peptide YY; GLP-1, glucagon-like peptide-1; ABCG1, ATP-binding cassette transporter G1; ALP, alkaline phosphatase; CPT-1, carnitine palmitoyl transferase-1; G6PDH, glucose-6-phosphate dehydrogenase; PAP, phosphatidic acid phosphohydrolase in the microsome.

quantitative analyses, which were performed with patients with dyslipidemia and demonstrated the Citrus effects on the levels of total cholesterol $\left[\mathrm{I}^{2}=94.5 \%(87.3 \% ; 97.6 \%)\right]$, triglycerides $\left[\mathrm{I}^{2}\right.$ $=95.6 \%(90.5 \% ; 98.0 \%)]$, LDL $\left[\mathrm{I}^{2}=96.6 \%\right.$ (93.0\%; 98.4\%)], and HDL $\left[I^{2}=81.4 \%(42.2 \% ; 94.0 \%)\right]$ (in both, $\left.\mathrm{n}=3 ; 100 \%\right)$.

The presentation of the forest graphs was distributed according to the results of the levels of total cholesterol, triglycerides, LDL, and HDL for preclinical and clinical studies. Through the global analysis of preclinical studies, a reduction of $-1.08 \mathrm{mmol} / \mathrm{L}$ (95\% CI: 1.23 ; -0.92 ; Figure $4 \mathrm{~A}$ ) was found in total cholesterol, equivalent to $41.76 \mathrm{mg} / \mathrm{dL}$; a reduction of $-0.50 \mathrm{mmol} / \mathrm{L}$ (95\% CI: 0.69 ; -0.31 ; Figure 4B) was found in triglycerides, corresponding to $44.28 \mathrm{mg} / \mathrm{dL}$; and a reduction of $-0.71 \mathrm{mmol} / \mathrm{L}$ (95\% CI: 0.97 ; -0.45 ; Figure $4 \mathrm{C}$ ) was found in LDL, what represents $27.45 \mathrm{mg} / \mathrm{dL}$. In addition, an increase of $0.11 \mathrm{mmol} / \mathrm{L}$ in the HDL levels was verified $(95 \%$ CI: 0.05; 0.17; Figure 4D), equivalent to $4.25 \mathrm{mg} / \mathrm{dL}$.

As illustrated in Figure 5, in the studies carried out on humans, the levels $(\mathrm{mg} / \mathrm{dL})$ of total cholesterol $(\mathrm{MD}=-42.03$, 95\% CI: $73.53 ;-10.52)$, triglycerides $(\mathrm{MD}=-62.41,95 \% \mathrm{CI}$ :
110.09; -14.73), and LDL (MD = -37.76, 95\% CI: 69.45; -6.06) were reduced after treating patients with Citrus extracts. In addition, it was observed that these patients had increased HDL levels ( $\mathrm{MD}=5.85,95 \% \mathrm{CI}: 0.41 ; 11.28)$. Although a high heterogeneity has been observed $\left(\mathrm{I}^{2}>75 \%\right)$, the synthase of the results obtained with individual studies favors treatment to the control of serum lipids. After the analysis of subgroups, high heterogeneity was still verified and the sensitivity analysis did not change the result of the general analysis (data not shown).

\section{DISCUSSION}

This systematic review compiled data from 25 studies on the effects of Citrus-based products in the control of dyslipidemia. Based on the countries where the studies were carried out, most of them were developed in countries of Asia (such as Korea and China) and the European Union, in addition to United States and Egypt, which are among the biggest Citrus product makers in the world (FAS, 2018). In fact, countries that have greater production 
TABLE 3 | Detailed description of the clinical studies of the effect of Citrus extract on hyperlipidemia included in the systematic review.

\begin{tabular}{|c|c|c|c|c|c|c|}
\hline $\begin{array}{l}\text { References/ } \\
\text { country }\end{array}$ & $\begin{array}{l}\text { Extract, plant } \\
\text { part and } \\
\text { species }\end{array}$ & Composition & Sample & Pathology & $\begin{array}{l}\text { Parameters } \\
\text { evaluated }\end{array}$ & Treatment protocol \\
\hline $\begin{array}{l}\text { Gorinstein et al., } \\
2007 \text { (Gorinstein } \\
\text { et al., 2007) } \\
\text { Israel }\end{array}$ & $\begin{array}{l}\text { Fresh fruit peels of } \\
\text { red grapefruit or } \\
\text { blond grapefruit } \\
\text { processed }\end{array}$ & $\begin{array}{l}\text { Red: } 51.5 \mathrm{mg} / 100 \mathrm{~g} \\
\text { Blond: } 49.3 \mathrm{mg} / 100 \mathrm{~g} \\
\text { Flavonoids (naringin) } \\
\text { Red: } 21.61 \mathrm{mg} / 100 \mathrm{~g} \\
\text { Blond: } 19.53 \mathrm{mg} / 100 \mathrm{~g} \\
\text { Total fibers } \\
\text { Red: } 1.39 \mathrm{~g} / 100 \mathrm{~g} \\
\text { Blond: } 1.37 \mathrm{~g} / 100 \mathrm{~g}\end{array}$ & $\begin{array}{l}57 \text { patients } \\
\text { (39-72 years) }\end{array}$ & $\begin{array}{l}\text { Hypertriglyceridemia and } \\
\text { coronary } \\
\text { disease }\end{array}$ & $\begin{array}{l}\text { CT, LDL, HDL, } \\
\text { TG, serum } \\
\text { antioxidant activity } \\
\text { by ABTS and } \\
\text { TEAC }\end{array}$ & $\begin{array}{l}\text { Daily supplementation with } \\
\text { red or blond grapefruits } \\
\text { associated with anti- } \\
\text { atherosclerosis diet for } \\
30 \text { days ( } n=19 \text { /group) }\end{array}$ \\
\hline $\begin{array}{l}\text { Mollace et al., } \\
2011 \text { (Mollace } \\
\text { et al., 2011) } \\
\text { Italy }\end{array}$ & $\begin{array}{l}\text { Polyphenolic } \\
\text { fraction of } C \text {. } \\
\text { bergamia peeled- } \\
\text { off fruits }\end{array}$ & $\begin{array}{l}\text { Neoeriocitrin }(77,700 \mathrm{ppm}) \\
\text { Naringin }(63,011 \mathrm{ppm}) \\
\text { Neohesperidin } \\
\text { (72,056 ppm) and } \\
\text { melitidine (15,606 ppm) } \\
\text { Brutieridine }(33,202 \mathrm{ppm})\end{array}$ & 237 patients & $\begin{array}{l}\text { Hyperlipemia associated or } \\
\text { not with hyperglycaemia }\end{array}$ & $\begin{array}{l}\text { TC, LDL, HDL, } \\
\text { TG, reactive } \\
\text { vasodilation }\end{array}$ & $\begin{array}{l}500 \text { or } 1,000 \mathrm{mg} / \text { day } \\
\text { encapsulated with } 50 \mathrm{mg} \\
\text { ascorbic acid, for } 30 \text { days } \\
\text { ( } \mathrm{n}=104-32 / \text { group) }\end{array}$ \\
\hline $\begin{array}{l}\text { Toth et al., } 2016 \\
\text { (Toth et al., } \\
2015 \text { ) } \\
\text { Italy }\end{array}$ & $\begin{array}{l}\text { Bergavit }^{\circledR} \\
\text { (Bergamot juice } \\
\text { derived extract, } C \text {. } \\
\text { bergamia) }\end{array}$ & $\begin{array}{l}150 \mathrm{mg} \text { of flavonoids } \\
16 \% \text { of neoeriocitrin } \\
47 \% \text { neohesperidin } \\
37 \% \text { naringin }\end{array}$ & $\begin{array}{l}80 \text { individuals } \\
\text { ( } 42 \text { men and } \\
38 \text { women) }\end{array}$ & $\begin{array}{l}\text { Moderate } \\
\text { hypercholesterolemia }\end{array}$ & $\begin{array}{l}\text { TC, LDL, HDL, TG, } \\
\text { VLDL, IDL, IMT, } \\
\text { LDL size }\end{array}$ & $\begin{array}{l}150 \mathrm{mg} / \text { day for } 6 \text { months } \\
(\mathrm{n}=80)\end{array}$ \\
\hline $\begin{array}{l}\text { Cai et al., } 2017 \\
\text { (Cai et al., 2017) } \\
\text { China }\end{array}$ & $\begin{array}{l}\text { C. bergamia extract } \\
\left.\text { (CitriCholess }^{\circledR}\right)\end{array}$ & $\begin{array}{l}25 \% \text { bioflavonoids, sterols } \\
\text { and orange oil ( } 820 \mathrm{mg} / \\
\text { day), vitamin C ( } 50 \mathrm{mg} / \\
\text { day), vitamin B6 ( } 20 \mathrm{mg} / \\
\text { daily), B12 (2,000 } \mathrm{\mu g} / \mathrm{day}) \text {, } \\
\text { and folic acid ( } 800 \mu \mathrm{g} / \text { day) }\end{array}$ & $\begin{array}{l}98 \text { older } \\
\text { people }\end{array}$ & $\begin{array}{l}\text { Dyslipidemia and arterial } \\
\text { hypertension and problems } \\
\text { of glucose intolerance }\end{array}$ & $\begin{array}{l}\text { TG, TC, LDL, HDL, } \\
\text { glucose, BW, WC, } \\
\mathrm{HC}, \text { WHR, } \\
\text { and BMl }\end{array}$ & $\begin{array}{l}500 \mathrm{mg} / \text { day for } 12 \text { weeks } \\
\text { ( } \mathrm{n}=48-50 / \text { group) }\end{array}$ \\
\hline
\end{tabular}

Legend: TC, total cholesterol; TG, triglycerides; LDL, low-density lipoprotein; HDL, high-density lipoprotein; TEAC, Trolox-equivalent antioxidant capacity; HR, heart rate; BP, blood pressure; BW, body weight; IMT, carotid intima-media thickness; BW, body weight (kg); WC, waist circumference (cm); HC, hip circumference (cm); WHR, waist-to-hip ratio; BMI, body mass index.

of natural resources tend to explore their products more from a commercial and scientific point of view.

Through the scientific analyses compiled, we can also verify that species of the genus Citrus have the potential to reduce the serum levels of total cholesterol (TC), triglycerides (TGs), LDL, and VLDL and increase HDL. Consequently, Citrus-based products reduced the body weight, lipid accumulation, and atherosclerosis risk by the modulation of proteins and genes involved in the lipid metabolism. Recently, a study with a standardized extract containing Citrus sinensis L. Osbeck associated with Citrus limon (Chiechio et al., 2021) also demonstrated an effect in controlling the levels of total cholesterol and triglycerides as well as glycemia, possibly due to its composition rich in anthocyanins, flavonoids, and hydroxycinnamic acids, reinstating the high potential of Citrus species in lipid control.

These effects were studied mainly in the animal models of dyslipidemia induced by cholesterol- or high-fat diets. In these protocols, lipids ingested are initially degraded by intestinal lipase and, in enterocytes, TGs are resynthesized and associated with cholesterol and lipoproteins (ApoB-48, ApoE, and ApoC-II), forming chylomicrons. These distributed fatty acids between tissues and their remnants are metabolized in the liver. In this organ, fatty acid and glucose activate metabolic pathways for energy synthesis and storage, so that excess citrate is converted by citrate lyase (ACLY) into acetyl-CoA, which by the action of acetyl-CoA carboxylase (ACC) forms malonyl-CoA. This metabolic intermediate is used by the cell to produce fatty acid through the action of the enzymes Stearoyl-CoA Desaturase-1 (SCD1) and fatty acid synthase (FAS), in addition to downregulating CPT-1, an important transporter of Acil-Coa into the mitochondria which enables its $\beta$-oxidation. These fatty acids give rise to triglyceride molecules. In addition, acetyl-CoA can participate in the synthetic pathway of cholesterol, forming HMG-CoA which is converted into mevalonic acid by HMGR. This originates the free cholesterol molecule, which can be 
TABLE 4 | Outcomes of the clinical studies included in this systematic review.

Reference

Experimental group

$(\mathrm{mg} / \mathrm{dL})$

Gorinstein et al. (Gorinstein et al. 2007)

Mollace et al. (Mollace et al., 2011)

aseline $(500 \mathrm{mg})$

LDL: 184.96

HDL: 34.55

TG: 266.87

Baseline (1,000 mg)

TC: 279.40

LDL: 189.70

HDL: 32.78

TG: 270.11

After 30 days $(500 \mathrm{mg})$

TC: 211.42

LDL: 132.79

HDL: 40.53

TG: 180.18

After 30 days $(1,000 \mathrm{mg})$

TC: 201.99

LDL: 125.34

HDL: 46.00

TG: 157.48

Toth et al. (Toth et al., 2015)

Baseline

TC: 224.28

LDL: 143.07

HDL: 54.13

TG: 132.86

Cai et al. (Cai et al., 2017)

Baseline

TC: 211.13

LDL: 131.09

HDL: 49.88

TG: 192.20

$500 \mathrm{mg}$

TC: 198.76

LDL: 121.03

HDL: 50.27

TG: 162.09
Control group (mg/dL)

Summary of results

Baseline:

TC: 306.26

LDL: 243.23

HDL: 46.20

TG: 205.49

Treated with capsules containing

$500 \mathrm{mg}$ of maltodextrin and $50 \mathrm{mg}$ of

ascorbic acid

Baseline

TC: 275.67

LDL: 186.31

HDL: 34.59

TG: 275.62

TC: 279.40

LDL: 185.64

HDL: 35.05

TG: 275.71
Red: $\downarrow$ TC, LDL, and TG

Blond: $\downarrow$ LDL only

Both: $\uparrow$ serum antioxidant activity, without change in $\mathrm{HR}$, $\mathrm{BP}, \mathrm{BW}$,

HDL

$\downarrow$ TC, TG, and LDL

$\uparrow \mathrm{HDL}$

$\downarrow$ glucose

$\uparrow$ reactive vasodilation
Baseline:

TC: 255.22

LDL: 177.88

HDL: 50.27

TG: 159.43

Baseline

TC: 217.32; LDL: 138.43; HDL: 51.81; TG:

170.94

TC: 210.36

LDL: 132.63

HDL: 52.20; TG: 172.71 $\downarrow \mathrm{TC}, \mathrm{LDL}, \mathrm{TG}$, and IMT

$\uparrow \mathrm{HDL}$, IDL, and LDL size

without changing VLDL

$\downarrow$ LDL

$\downarrow$ BW, WC,

WHR, and BMl

without changing TG, TC, HDL, glucose, HC

Legend: TC, total cholesterol; TG, triglycerides; LDL, low-density lipoprotein; HDL, high-density lipoprotein; TEAC, Trolox-equivalent antioxidant capacity; HR, heart rate; BP, blood pressure; BW, body weight; IMT, carotid intima-media thickness; BW, body weight (kg); WC, waist circumference (cm); HC, hip circumference (cm); WHR, waist-to-hip ratio; BMI, body mass index.

esterified by acyl-CoA:cholesterol acyltransferase (ACAT) or converted into bile acids by CYP7A1. TG, free cholesterol, and cholesterol ester conjugate with lipoproteins (ApoE, ApoC-II, and ApoB-100) constituting the VLDL molecule (TGs > cholesterol). This lipoprotein distributes fatty acids to tissues by the action of lipoprotein lipase (LPL) and becomes IDL (TGs $\approx$ cholesterol, ApoB-100, ApoE) and later LDL (TGs, < cholesterol, ApoB-100). That way, high-lipid diets increase the plasmatic concentrations of TG, TC, VLDL, IDL, and LDL (DiNicolantonio and O'Keefe, 2018; Andreadou et al., 2020). These mechanisms can be observed in Figure 6 (black lines).

Through this review, it was found that the effect of Citrusbased products on the release of adipocytokines and their signaling pathways has been studied. These molecules are produced by adipose tissue and control several metabolic pathways, in addition to affecting the state of hunger and 


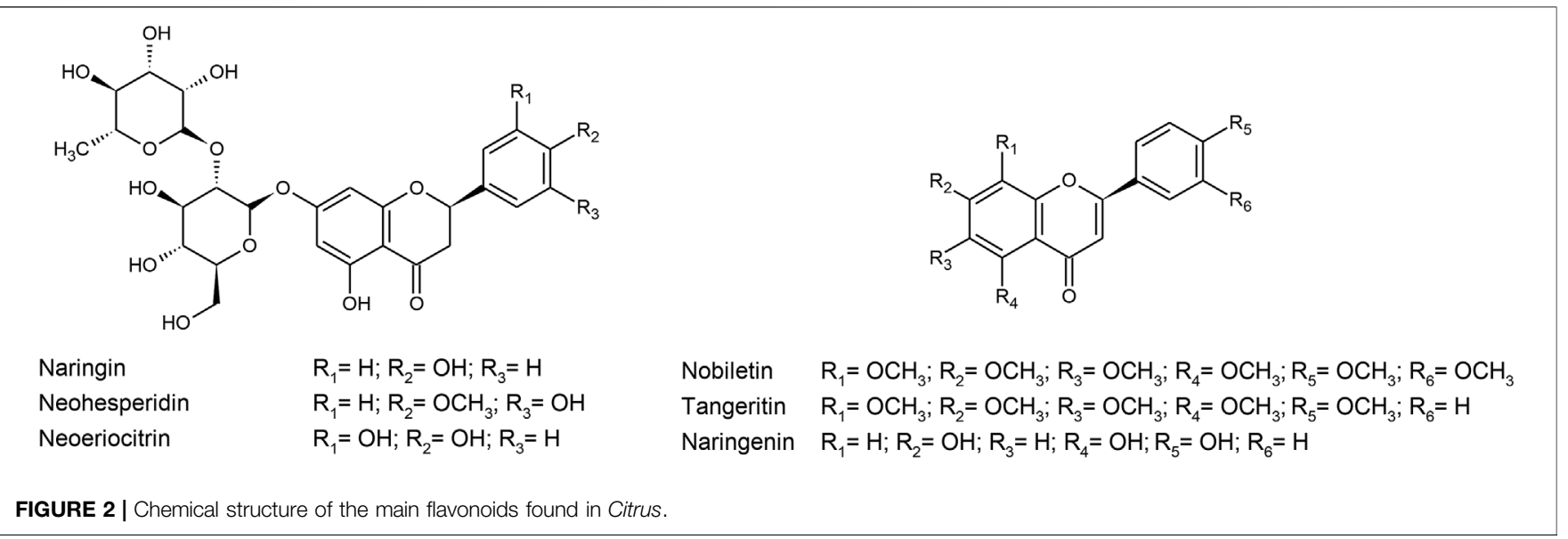

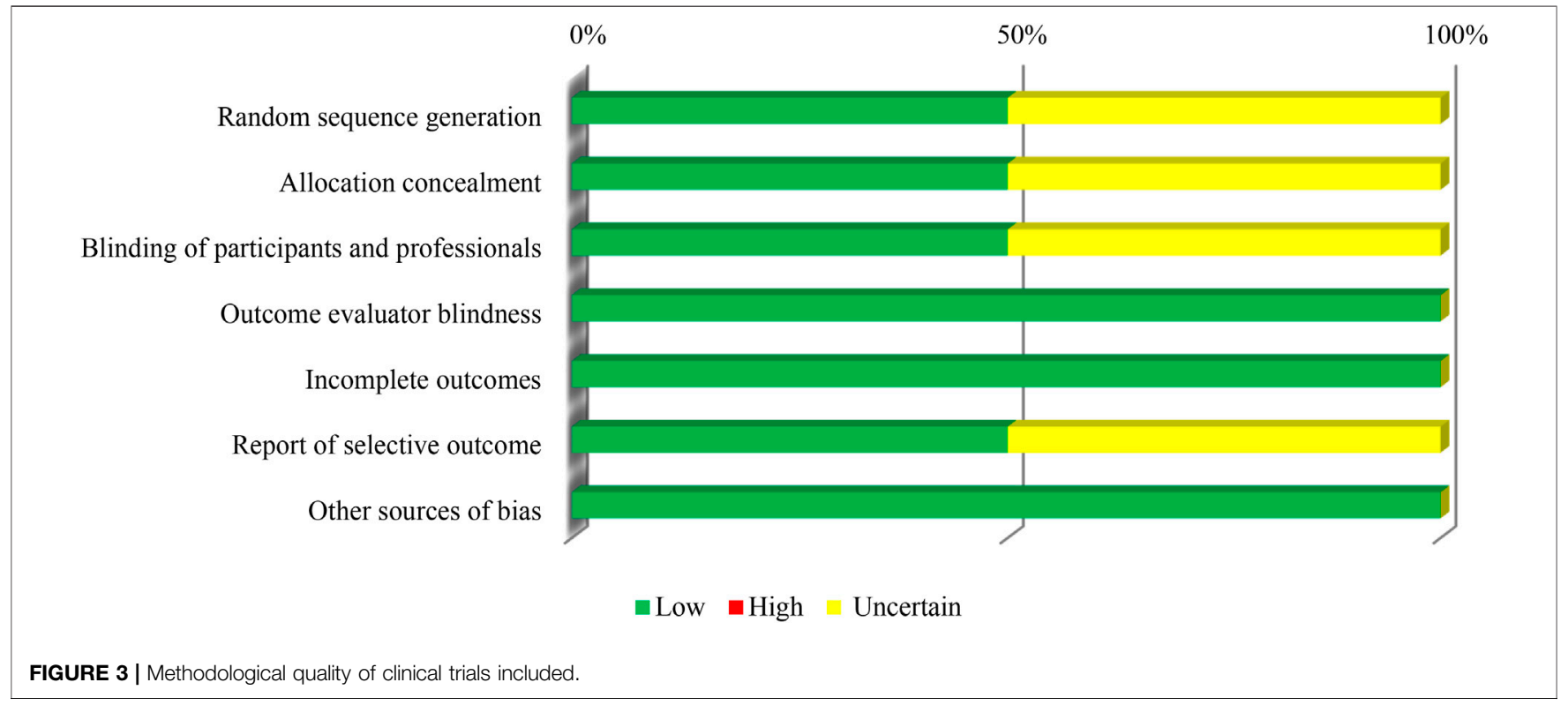

satiety and being related to the development of coronary diseases and metabolic disorders (Cao, 2014). Citrus products reduce adiponectin (Kang et al., 2012), whose action on specific receptors (AdipoR) increases the phosphorylation of LKB1 and AMPK (Kang et al., 2012; Shin et al., 2016). It negatively modulates ACC (Kang et al., 2012; Shin et al., 2016), reducing malonyl-Coa levels and, consequently, increasing CPT-1 (Shin et al., 2016); in addition, it decreases the HMGR activity (Bok et al., 1999; Shin et al., 2016) and modulates genes like LXR (Ding et al., 2012; Lu et al., 2013) and PPAR (Kim et al., 2013; Shin et al., 2016; Lu et al., 2018). Through these genes, Citrus regulates several protein targets involved in lipogenesis (FAS, aP2, ACC) (Ding et al., 2012; Lu et al., 2013; Shin et al., 2016), lipoprotein formation and metabolism (ApoE, LPL) (Ding et al., 2012; Lu et al., 2013), cholesterol metabolism (CYP7A1) (Ding et al., 2012), and cholesterol and lipid efflux (ABCG1 and ABCA1) (Ding et al., 2012; Lu et al., 2013). At the same time, its ability to stimulate the PKA-HSL pathway has also been observed (Kang et al., 2012), increasing the degradation of TG in glycerol and fatty acid, in addition to reducing the activity of ACAT (Bok et al., 1999), which contributes to the reduction of cholesterol ester levels. It is worth mentioning that bio-products based on Citrus help in glycemic control (Mollace et al., 2011; Ding et al., 2012; Kim et al., 2013; Lu et al., 2013; Raasmaja et al., 2013; Muhtadi et al., 2015; Dinesh and Hegde, 2016; Ashraf et al., 2017; Fayek et al., 2017), possibly by reducing resistin (Kim et al., 2013), an adipocytokine whose increase has been associated with insulin resistance, atherosclerosis, oxidative stress, and inflammation. All of these molecular events result in decreased lipogenesis and increased lipid oxidation, contributing to the control of the lipid profile (Figure 6).

However, some results seem contradictory, such as the effect of Citrus in reduction of the mRNA levels of PPAR $\gamma$ target genes, including ACO and UCP2 in the liver tissue (Ding et al., 2012). 


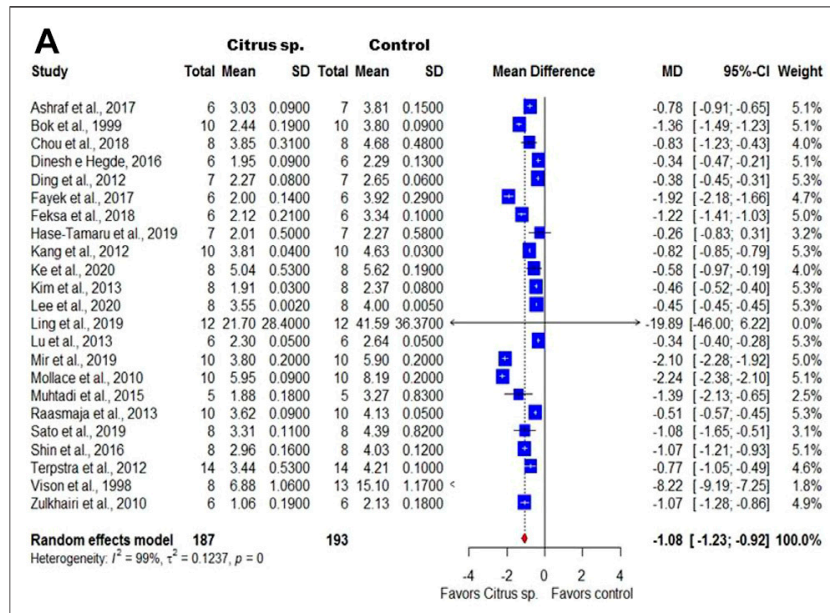

B
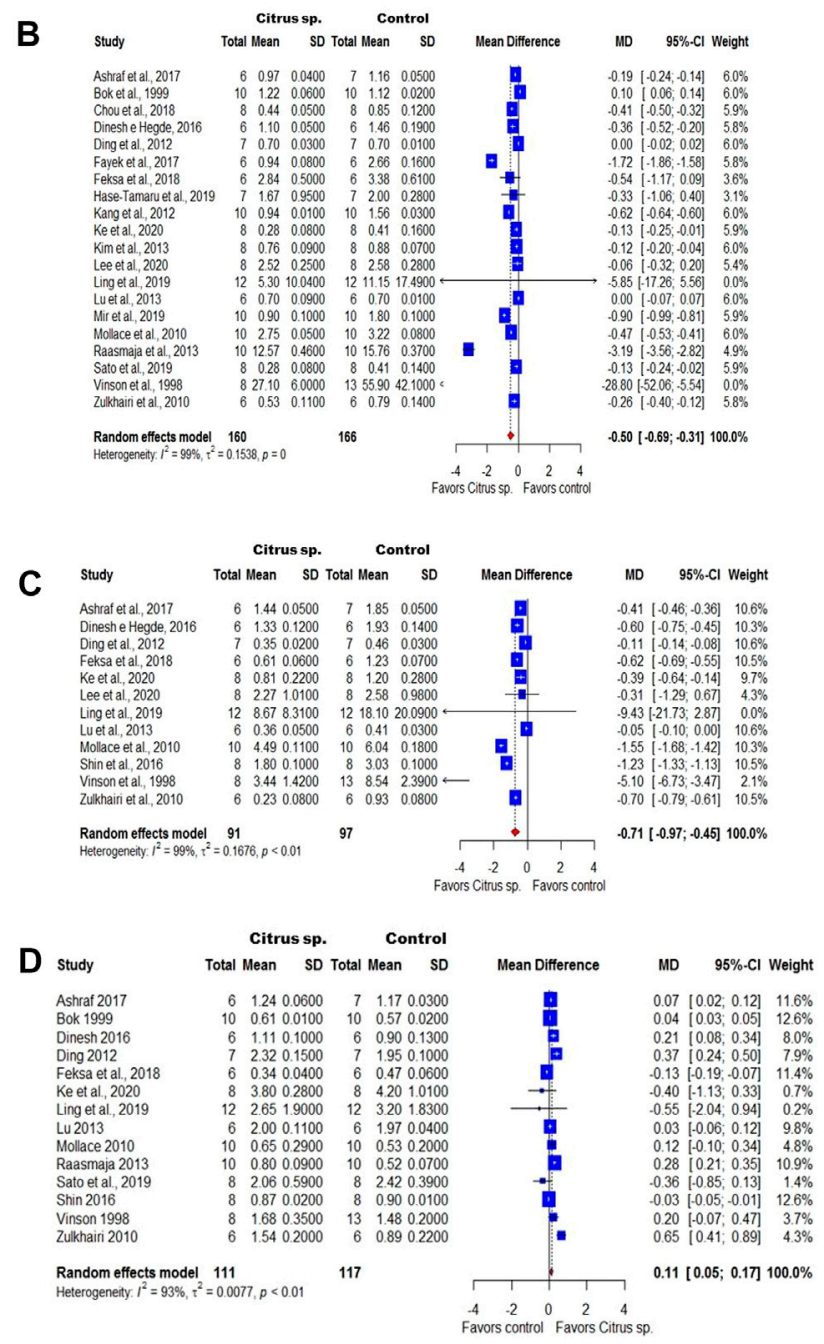

FIGURE 4 | Forest plot of the preclinical studies that evaluated the effect of Citrus species on total cholesterol (A), triglycerides (B), LDL (C), and HDL (D) levels. The numbers on the $x$-axis indicate the effect of the treatment and its favoring. SD: standard deviation of the differences. MD: difference between the means.
ACO is the first enzyme of peroxisomal $\beta$-oxidation which will reduce the accumulation of lipids in the liver and promote its excretion (Ferdinandusse et al., 2007). On the other hand, UCP2 is an uncoupling protein which acts as a carrier of protons present in the inner membrane of mitochondria and contributes to thermogenesis, being a positive factor for the prevention of obesity (Brand and Esteves, 2005). Thus, upregulation of these mRNAs would contribute to the observed outcomes. However, the absence of baseline conditions for these targets makes it difficult to understand these data, so further studies are needed to elucidate this mechanism.

Similarly, Citrus seems to increase CD36 (Ding et al., 2012), the fatty acid translocase protein that facilitates the transport of fatty acids, the hepatic uptake of fatty acids, and the accumulation of fat and has a high affinity for binding with the oxidized LDL molecule, increasing the inflammatory activity and being a main condition for the development of atherosclerosis and thrombosis (Pepino et al., 2014). However, the correlation with the observed outcomes also needs to be further investigated, since the experimental conditions of the study do not allow a thorough analysis of this target in the experimental model used, as well as in the primary outcome studied.

It is also worth noting that some studies have shown that Citrus can help control hunger promoting the modulation of ghrelin. Known as "Hunger Hormone," this peptide is produced by endocrine cells present in the stomach and acts in the control of hunger, adiposity, and glucose- and energy-homeostasis, among other functions (Pradhan et al., 2013). More over, Citrus also downregulates leptin and GLP-1 levels, which are involved with satiety control. Leptin, a hormone produced by adipose tissue, plays an important role in the control of energy homeostasis, the excess and resistance of which are associated with obesity, leading to failures in the signaling mechanisms associated with decreased nutrition and body weight control (Pan and Myers, 2018). On the other hand, glucagon-like peptide 1 (GLP-1) is a gut hormone that promotes satiety; potentiates insulin release and suppression of glucagon release in response to nutrient intake; and decreases postprandial plasma levels of glucose (Andersen et al., 2018). Thus, the effects observed for Citrus in the reduction of GLP-1 may be related to overnight fasting or long-term regulation of eating and energy metabolism, requiring further investigation.

The notations are as follows: ABCA1: ATP-binding cassette transporter A1; ABCG1: ATP-binding cassette transporter G1; ACAT: acyl-CoA:cholesterol acyltransferase; ACC: acetylCoA carboxylase; ACLY: citrate lyase; ACO: acyl-CoA oxidase; AdipoR: adiponectin receptor; AMPK: AMPactivated protein kinase; aP2: adipocyte fatty-acid-binding protein; ApoB-100: apolipoprotein B-100; ApoC-II: apolipoprotein $\mathrm{C} 2$; ApoE: apolipoprotein E; CD36: cluster of differentiation 36; CPT-1: carnitine palmitoyl transferase1; CYP7A1: cholesterol 7a-hydroxylase; FAS: fatty acid synthase; GLUT 4: glucose transporter 4; HMGR: 3hydroxy-3-methylglutaryl-coenzyme A reductase; HSL: 


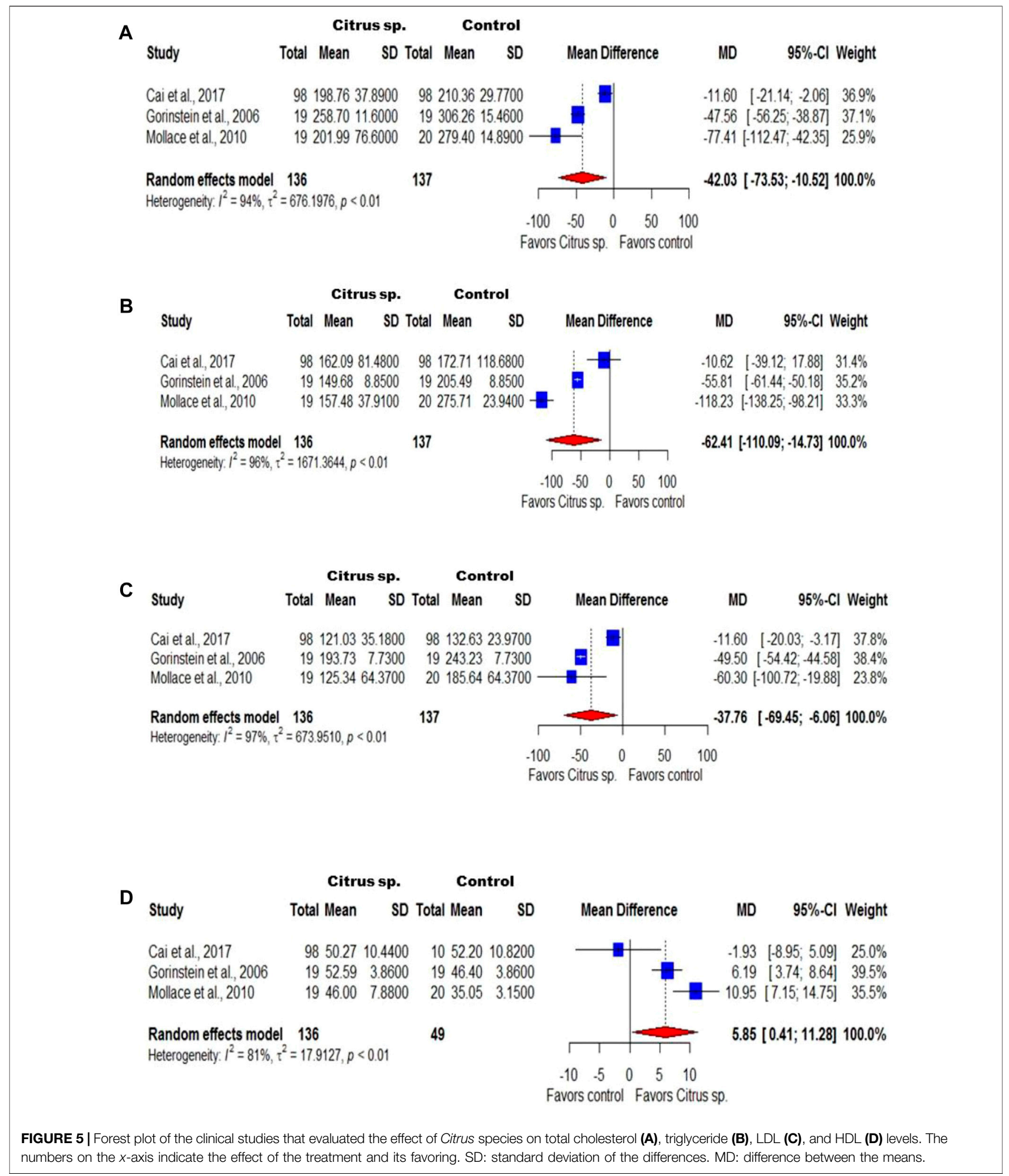

hormone-sensitive lipase; IDL: intermediate low-density lipoprotein; LDL: low-density lipoprotein; LKB1: liver kinase B1; LPL: lipoprotein lipase; LXR: liver $\mathrm{X}$ receptor;
p-ACC: phosphorylated acetyl-CoA carboxylase; PKA: cAMP-dependent protein kinase; PPAR: peroxisome proliferator-activated receptor; SCD1: Stearoyl-CoA 


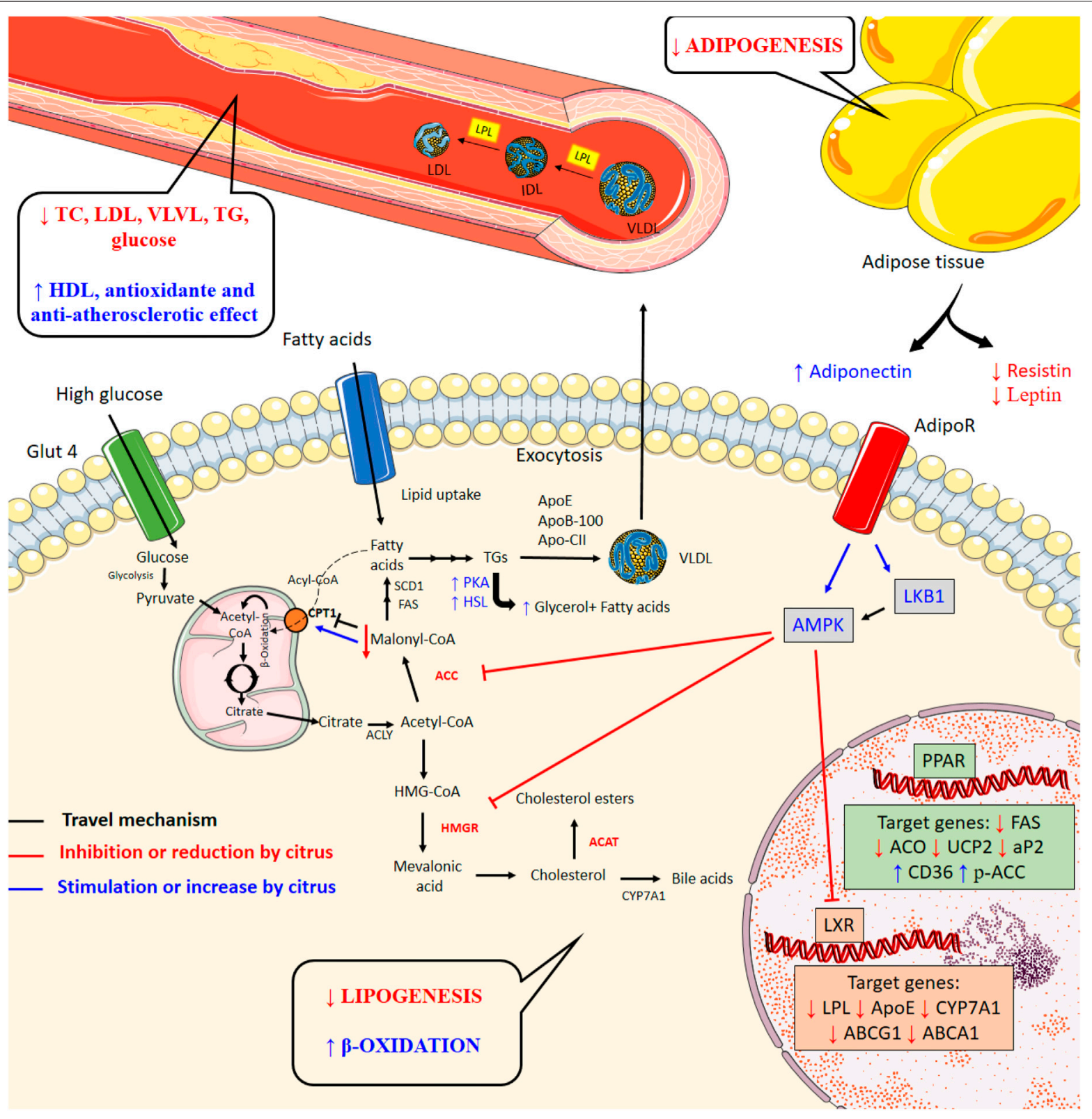

FIGURE 6 | Biochemical and tissue changes caused by diets high in fat and calories (black lines) and mechanisms of action of Citrus products upon metabolic disorders associated with hyperlipidemia (blue lines indicate activation and red lines indicate inhibition).

Desaturase-1; TC: total cholesterol; TGs: triglycerides; UCP2: uncoupling protein 2; VLDL: very low-density lipoprotein.

The effects of Citrus bioproducts on the lipid profile may be related to the presence of bioactive compounds, with emphasis on the flavonoids, such as naringin, hesperidin, neohesperidin, neoeriocitrin, nobiletin, tangeretin, and naringenin as compiled in this review. In fact, these compounds are believed to play a very significant role in reducing the levels of total cholesterol, triglycerides, and LDL (Mulvihill and Huff, 2012; Assini et al., 2013; Kou et al., 2017; Zeka et al., 2017). Several studies have shown that naringin reduces the HMGR activity more potently than does vitamin E (Choi et al., 2001; Lee et al., 2001), as well as decreasing the action of ACAT (Kim et al., 2006), which contributed to hypocholesterolemic action and higher excretion of fecal sterols (Jeon et al., 2004). Similarly, hesperidin reduces plasma cholesterol in hypercholesterolemic rats by decreasing ACAT and HMGR (Lee et al., 1999; Lee et al., 2012) besides changing the expressions of genes encoding PPARs and the LDL receptor (Akiyama et al., 2009). A recent study demonstrated that neohesperidin is also able to regulate the lipid metabolism in vivo and in vitro via FGF21 and AMPK/SIRT1/PGC-1 $\alpha$ signaling axis (Wu et al., 2017). Furthermore, the non-glycoside Citrus flavonoid, naringenin, stimulates the hepatic fatty acid oxidation via PPAR $\gamma$ and prevents lipogenesis in both the liver and the muscle, reducing the serum lipid levels (Mulvihill et al., 2009). 
In this review, we also observed that the Citrus products act by reducing the atherogenic index or tissue manifestations associated with atherosclerosis (Vinson et al., 1998; Bok et al., 1999; Zulkhairi et al., 2010). In fact, the polyphenolic compounds and flavonoids found in the Citrus species have antioxidant (Vinson et al., 1998; Gorinstein et al., 2007; Zulkhairi et al., 2010; Craft et al., 2012) and anti-inflammatory properties, in addition to their ability to decrease LDL levels, inhibiting the formation of atherosclerotic plaques (Tripoli et al., 2007; Assini et al., 2013; Onakpoya et al., 2017). Naringin, for example, reduces plaque progression once it decreases non-highdensity lipoprotein cholesterol concentrations and biomarkers of endothelial dysfunction and inhibits the expression of ICAM-1 in endothelial cells, preventing immune cell adhesion and infiltration in the vascular wall (Choe et al., 2001; Chanet et al., 2012).

Confirming the results of the systematic review, the meta-analysis of preclinical studies indicated that Citrus products reduce the total cholesterol, triglycerides, and LDL levels by $-41.76,-44.28$, and $-27.45 \mathrm{mg} / \mathrm{dL}$, respectively, while increasing the HDL levels by $4.25 \mathrm{mg} / \mathrm{dL}$. Similar results were observed in the clinical studies, in which the Citrus species induce a reduction in the total cholesterol, triglycerides, and LDL levels by $-42.03,-62.41$, and $-37.76 \mathrm{mg} / \mathrm{dL}$, respectively, whereas the HDL levels increased by an average of $5.85 \mathrm{mg} / \mathrm{dL}$.

In the meta-analysis published by Onakpoyaa et al. (2015) (Onakpoya et al., 2017), performed with two clinical trials about the effect of grapefruits on the lipid profile, significant effects were observed only for the increase in HDL, without TC and LDL changes. More recently, a meta-analysis published by Kou et al. (2017) showed that the sizes of effect measures for LDL and total cholesterol presented significant results in the group of patients treated with Citrus juice, without considerable changes in HDL and TG levels. The divergence between the results presented in our meta-analysis compared to those previously published is justified by the broader scope of our question, as well as the inclusion of more recent studies, which have confirmed the contribution of Citrus-based products in the control of blood lipids.

Through the analysis of the risk of bias, it can be observed that the preclinical studies have a satisfactory average score, with some limitations in the methodological description of the studies and the results. Similarly, clinical studies had limitations in reporting or methodology in terms of blinding, allocation, randomization, and reporting of results. The use of tools to assess the risk of bias in the studies included in the systematic reviews has been widely well supported by groups such as SYRCLE (Hooijmans et al., 2014), ARRIVE (Kilkenny et al., 2010), and Cochrane (Cochrane Training, 2019), since the credibility of the results and the strength of the evidence depend on the methodological criteria of the studies (Busch et al., 2020).

Thus, although the results obtained are favorable to the treatment with Citrus extracts, the methodological limitations and high heterogeneity of the studies included in the meta-analysis weaken the evidence about the real benefits of this intervention. In addition, the studies do not provide information on effective dose, bioavailability, efficacy, and safety. These parameters are required to propel the use of these promising therapeutic agents into the clinical area. For this reason, further studies are needed to strengthen the evidence of the effects of Citrus on dyslipidemia.

This systematic review presents as limitations the low evidence found due to the high variability of the studies and variation of the methodological protocols of the articles. Among them, we can mention the differences in the induction of dyslipidemia, routes of administration, and types of extracts, besides the absence of baseline serum levels of lipids for comparison after the induction and inconclusive report. Finally, as in our review, of the 25 studies included in the meta-analysis, only 3 presented results in humans; we chose not to use the GRADE system. For this reason, we believe that further clinical studies are needed to provide sufficient scientific support to measure the effectiveness of Citrus effects on dyslipidemia.

\section{CONCLUSION}

From the compilations of the studies, one can suggest that the Citrus extract has a potential effect in dyslipidemia control, both in the preclinical studies and clinical trials. These effects can be associated with the presence of bioactive compounds, as flavonoids, which act synergistically through several pathways, causing inhibition of lipogenesis and activating $\beta$-oxidation. However, due to the high heterogeneity of the reposted findings, further studies are needed to increase the strength of clinical evidence of the action of Citrus extracts on the control of dyslipidemia and increase the strength of that evidence.

\section{DATA AVAILABILITY STATEMENT}

The original contributions presented in the study are included in the article/Supplementary Material; further inquiries can be directed to the corresponding author.

\section{AUTHOR CONTRIBUTIONS}

Ideation and preparation of the review: $\mathrm{BC}$ and $\mathrm{AG}$; search and selection of studies: $\mathrm{BC}$ and $\mathrm{LN}$; third evaluation for discrepancy analysis: AG; qualitative data extraction: $\mathrm{BC}, \mathrm{LN}$, and JN; quantitative data extraction: $\mathrm{BC}$ and VG; meta-analysis: $\mathrm{BC}, \mathrm{VG}$, and PZ; writing and finalizing the review: BC, DT, and AG.

\section{FUNDING}

The authors acknowledge grants from the Foundation for Support of Research and Technological Innovation of the State of Sergipe (Fundação de Apoio à Pesquisa e Inovação Tecnológica do Estado de Sergipe: FAPITEC/SE, EDITAL CAPES/FAPITEC/SE N 10/2016 PROMOB 1995/2017), National Council for Scientific and Technological Development (Conselho Nacional de Desenvolvimento Científico e Tecnológico: CNPq/Brazil), Coordination for the Improvement of Personnel Higher Education (Coordenação de Aperfeiçoamento de Pessoal de Nível Superior: CAPES/Brazil), and Federal University of Sergipe. 


\section{ACKNOWLEDGMENTS}

We are grateful for the support given by Patrícia K. Ziegelmann in the elaboration of the meta-analysis and to teacher Abilio Borghi for the assistance with English language review.

\section{REFERENCES}

Abid, H., Abid, Z., and Abid, S. (2021). Atherogenic Indices in Clinical Practice and Biomedical Research: A Short Review. Baghdad J. Biochem. Appl. Biol. Sci. 2 (02), 60-70. doi:10.47419/bjbabs.v2i02.52

Adel Mehraban, M. S., Tabatabaei-Malazy, O., Rahimi, R., Daniali, M., Khashayar, P., and Larijani, B. (2021). Targeting Dyslipidemia by Herbal Medicines: A Systematic Review of Meta-Analyses. J. Ethnopharmacology 280, 114407. doi:10.1016/j.jep.2021.114407

Akiyama, S., Katsumata, S., Suzuki, K., Nakaya, Y., Ishimi, Y., and Uehara, M. (2009). Hypoglycemic and Hypolipidemic Effects of Hesperidin and Cyclodextrin-Clathrated Hesperetin in Goto-Kakizaki Rats with Type 2 Diabetes. Biosci. Biotechnol. Biochem. 73 (12), 2779-2782. doi:10.1271/bbb. 90576

Alam, M., Kauter, K., and Brown, L. (2013). Naringin Improves Diet-Induced Cardiovascular Dysfunction and Obesity in High Carbohydrate, High Fat DietFed Rats. Nutrients 5 (3), 637-650. doi:10.3390/nu5030637

Andersen, A., Lund, A., Knop, F. K., and Vilsbøll, T. (2018). Glucagon-like Peptide 1 in Health and Disease. Nat. Rev. Endocrinol. 14 (7), 390-403. doi:10.1038/ s41574-018-0016-2

Andreadou, I., Schulz, R., Badimon, L., Adameová, A., Kleinbongard, P., Lecour, S., et al. (2020). Hyperlipidaemia and Cardioprotection: Animal Models for Translational Studies. Br. J. Pharmacol. 177 (23), 5287-5311. doi:10.1111/ bph.14931

Ashraf, H., Butt, M. S., Iqbal, M. J., and Suleria, H. A. R. (2017). Citrus Peel Extract and Powder Attenuate Hypercholesterolemia and Hyperglycemia Using Rodent Experimental Modeling. Asian Pac. J. Trop. Biomed. 7 (10), 870-880. doi:10.1016/j.apjtb.2017.09.012

Assini, J. M., Mulvihill, E. E., and Huff, M. W. (2013). Citrus Flavonoids and Lipid Metabolism. Curr. Opin. Lipidol. 24 (1), 34-40. doi:10.1097/MOL. ob013e32835c07fd

Atmosudigdo, I. S., Lim, M. A., Radi, B., Henrina, J., Yonas, E., Vania, R., et al. (2021). Dyslipidemia Increases the Risk of Severe COVID-19: A Systematic Review, Meta-analysis, and Meta-regression. Clin. Med. Insights: Endocrinol. Diabetes 4, 1-7. doi:10.1177/1179551421990675

Ballard, C. R., Galvão, T. F., Cazarin, C. B. B., and Maróstica, M. R. (2019). Effects of Polyphenol-Rich Fruit Extracts on Diet-Induced Obesity in Rodents: Systematic Review and Meta-Analysis. Curr. Pharm. Des. 25 (32), 3484-3497. doi:10.2174/1381612824666191010170100

Bok, S. H., Lee, S. H., Park, Y. B., Bae, K. H., Son, K. H., Jeong, T. S., et al. (1999). Plasma and Hepatic Cholesterol and Hepatic Activities of 3-Hydroxy-3Methyl-Glutaryl-CoA Reductase and Acyl CoA: Cholesterol Transferase Are Lower in Rats Fed Citrus Peel Extract or a Mixture of Citrus Bioflavonoids. J. Nutr. 129 (6), 1182-1185. doi:10.1093/jn/129.6.1182

Brand, M. D., and Esteves, T. C. (2005). Physiological Functions of the Mitochondrial Uncoupling Proteins UCP2 and UCP3. Cell Metab 2 (2), 85-93. doi:10.1016/j.cmet.2005.06.002

Busch, L. M., Sun, J., Cui, X., Eichacker, P. Q., and Torabi-Parizi, P. (2020). Checkpoint Inhibitor Therapy in Preclinical Sepsis Models: a Systematic Review and Meta-Analysis. Intensive Care Med. Exp. 8 (1), 7. doi:10.1186/ s40635-019-0290-x

Cai, Y., Xing, G., Shen, T., Zhang, S., Rao, J., and Shi, R. (2017). Effects of 12-week Supplementation of Citrus Bergamia Extracts-Based Formulation CitriCholess on Cholesterol and Body Weight in Older Adults with Dyslipidemia: a Randomized, Double-Blind, Placebo-Controlled Trial. Lipids Health Dis. 16 (1), 251. doi:10.1186/s12944-017-0640-1

Cao, H. (2014). Adipocytokines in Obesity and Metabolic Disease. J. Endocrinol. 220 (2), T47-T59. doi:10.1530/JOE-13-0339

\section{SUPPLEMENTARY MATERIAL}

The Supplementary Material for this article can be found online at: https://www.frontiersin.org/articles/10.3389/fphar.2022.822678/ full\#supplementary-material

Chanet, A., Wizinska, P., Polakof, S., Mazur, A., Bennetau-Pelissero, C., Morand, C., et al. (2012). Naringin at a Nutritional Dose Modulates Expression of Genes Related to Lipid Metabolism and Inflammation in Liver of Mice Fed a High-Fat Diet. Nutr. Aging 1 (2), 113-123. doi:10.3233/nua-2012-0010

Chiechio, S., Zammataro, M., Barresi, M., Amenta, M., Ballistreri, G., Fabroni, S., et al. (2021). A Standardized Extract Prepared from Red Orange and Lemon Wastes Blocks High-Fat Diet-Induced Hyperglycemia and Hyperlipidemia in Mice. Molecules 26 (14), 4291. doi:10.3390/molecules26144291

Choe, S. C., Kim, H. S., Jeong, T. S., Bok, S. H., and Park, Y. B. (2001). Naringin Has an Antiatherogenic Effect with the Inhibition of Intercellular Adhesion Molecule-1 in Hypercholesterolemic Rabbits. J. Cardiovasc. Pharmacol. 38 (6), 947-955. doi:10.1097/00005344-200112000-00017

Choi, M. S., Do, K. M., Park, Y. S., Jeon, S. M., Jeong, T. S., Lee, Y. K., et al. (2001). Effect of Naringin Supplementation on Cholesterol Metabolism and Antioxidant Status in Rats Fed High Cholesterol with Different Levels of Vitamin E. Ann. Nutr. Metab. 45 (5), 193-201. doi:10.1159/000046729

Chou, Y. C., Ho, C. T., and Pan, M. H. (2018). Immature Citrus Reticulata Extract Promotes Browning of Beige Adipocytes in High-Fat Diet-Induced C57BL/6 Mice. J. Agric. Food Chem. 66 (37), 9697-9703. doi:10.1021/acs.jafc.8b02719

Cochrane Training (2019). Cochrane Handbook for Systematic Reviews of Interventions. Wiley Online Books. Available at: : https://onlinelibrary.wiley. com/doi/book/10.1002/9781119536604.

Craft, B. D., Kerrihard, A. L., Amarowicz, R., and Pegg, R. B. (2012). Phenol-Based Antioxidants and the In Vitro Methods Used for Their Assessment. Compr. Rev. Food Sci. Food Saf. 11 (2), 148-173. doi:10.1111/j.1541-4337.2011.00173.x

Dinesh, S. S., and Hegde, K. (2016). Antiobesity Activity of Ethanolic Extract ofCitrus Maximaleaves on Cafeteria Diet Induced and Drug Induced Obese Rats. Rese. Jour. Pharm. Technol. 9 (7), 907-912. doi:10.5958/0974-360x.2016.00173.6

Ding, X., Fan, S., Lu, Y., Zhang, Y., Gu, M., Zhang, L., et al. (2012). Citrus Ichangensis Peel Extract Exhibits Anti-metabolic Disorder Effects by the Inhibition of PPAR $\gamma$ and LXR Signaling in High-Fat Diet-Induced C57BL/6 Mouse. Evid. Based Complement. Alternat Med. 2012, 678592. doi:10.1155/2012/678592

DiNicolantonio, J. J., and O'Keefe, J. H. (2018). Effects of Dietary Fats on Blood Lipids: a Review of Direct Comparison Trials. Open Heart 5 (2), e000871. doi:10.1136/openhrt-2018-000871

FAS (2018). Citrus: World Markets and Trade. Washington: USDA Foreign Agricultural Service. Available at: https://www.fas.usda.gov/data/citrusworld-markets-and-trade.

Fayek, N. M., El-Shazly, A. H., Abdel-Monem, A. R., Moussa, M. Y., Abd-Elwahab, S. M., and El-Tanbouly, N. D. (2017). Comparative Study of the Hypocholesterolemic, Antidiabetic Effects of Four Agro-Waste Citrus Peels Cultivars and Their HPLC Standardization. Revista Brasileira de Farmacognosia 27 (4), 488-494. doi:10.1016/j.bjp.2017.01.010

Feksa, D. L., Coelho, R. P., Aparecida da Costa Güllich, A., Dal Ponte, E. S., da Costa Escobar Piccoli, J., and Manfredini, V. (2018). Extract of Citrus Maxima (Pummelo) Leaves Improve Hepatoprotective Activity in Wistar Rats Submitted to the Induction of Non-alcoholic Hepatic Steatosis. Biomed. Pharmacother. 98, 338-346. doi:10.1016/j.biopha.2017.12.070

Ferdinandusse, S., Denis, S., Hogenhout, E. M., Koster, J., van Roermund, C. W., IJlst, L., et al. (2007). Clinical, Biochemical, and Mutational Spectrum of Peroxisomal Acyl-Coenzyme A Oxidase Deficiency. Hum. Mutat. 28 (9), 904-912. doi:10.1002/humu.20535

Fruchart, J. C., Sacks, F. M., Hermans, M. P., Assmann, G., Brown, W. V., Ceska, R., et al. (2008). The Residual Risk Reduction Initiative: a Call to Action to Reduce Residual Vascular Risk in Dyslipidaemic Patient. Diab Vasc. Dis. Res. 5 (4), 319-335. doi:10.3132/dvdr.2008.046

Gattuso, G., Barreca, D., Gargiulli, C., Leuzzi, U., and Caristi, C. (2007). Flavonoid Composition of Citrus Juices. Molecules 12 (8), 1641-1673. doi:10.3390/ 12081641 
Geleijnse, J. M., Launer, L. J., Hofman, A., Pols, H. A., and Witteman, J. C. (1999). Tea Flavonoids May Protect against Atherosclerosis: the Rotterdam Study. Arch. Intern. Med. 159 (18), 2170-2174. doi:10.1001/archinte.159.18.2170

Gorinstein, S., Leontowicz, H., Leontowicz, M., Krzeminski, R., Gralak, M., Jastrzebski, Z., et al. (2007). Effect of Hesperidin and Naringin on the Plasma Lipid Profile and Plasma Antioxidant Activity in Rats Fed a Cholesterol-Containing Diet. J. Sci. Food Agric. 87 (7), 1257-1262. doi:10. $1002 /$ jsfa. 2834

Hase-Tamaru, S., Okushima, A., Miyata, Y., Nakayama, H., Aramaki, S., Miyata, Y., et al. (2019). Unripe and Discarded Satsuma Mandarin (Citrus Unshiu MARC.) Improves Lipid Metabolism in Rats. Fstr 25, 705-713. doi:10.3136/fstr.25.705

Higgins, J. P., and Thompson, S. G. (2002). Quantifying Heterogeneity in a MetaAnalysis. Stat. Med. 21 (11), 1539-1558. doi:10.1002/sim.1186

Hooijmans, C. R., Rovers, M. M., de Vries, R. B., Leenaars, M., Ritskes-Hoitinga, M., and Langendam, M. W. (2014). SYRCLE's Risk of Bias Tool for Animal Studies. BMC Med. Res. Methodol. 14, 43. doi:10.1186/1471-2288-14-43

Ingersgaard, M. V., Helms Andersen, T., Norgaard, O., Grabowski, D., and Olesen, K. (2020). Reasons for Nonadherence to Statins - A Systematic Review of Reviews. Patient Prefer Adherence 14, 675-691. doi:10.2147/PPA.S245365

Jeon, S. M., Park, Y. B., and Choi, M. S. (2004). Antihypercholesterolemic Property of Naringin Alters Plasma and Tissue Lipids, Cholesterol-Regulating Enzymes, Fecal Sterol and Tissue Morphology in Rabbits. Clin. Nutr. 23 (5), 1025-1034. doi:10.1016/j.clnu.2004.01.006

Kang, S. I., Shin, H. S., Kim, H. M., Hong, Y. S., Yoon, S. A., Kang, S. W., et al. (2012). Immature Citrus Sunki Peel Extract Exhibits Antiobesity Effects by $\beta$ oxidation and Lipolysis in High-Fat Diet-Induced Obese Mice. Biol. Pharm. Bull. 35 (2), 223-230. doi:10.1248/bpb.35.223

Ke, Z., Zhao, Y., Tan, S., Chen, H., Li, Y., Zhou, Z., et al. (2020). Citrus Reticulata Blanco Peel Extract Ameliorates Hepatic Steatosis, Oxidative Stress and Inflammation in HF and MCD Diet-Induced NASH C57BL/6 J Mice. J. Nutr. Biochem. 83, 108426. doi:10.1016/j.jnutbio.2020.108426

Khan, W., Augustine, D., Rao, R. S., Patil, S., Awan, K. H., Sowmya, S. V., et al. (2021). Lipid Metabolism in Cancer: A Systematic Review. J. Carcinog 20, 4. doi:10.4103/jcar.JCar_15_20

Kilkenny, C., Browne, W. J., Cuthill, I. C., Emerson, M., and Altman, D. G. (2010). Improving Bioscience Research Reporting: The ARRIVE Guidelines for Reporting Animal Research. Plos Biol. 8 (6), e1000412. doi:10.1371/journal. pbio. 1000412

Kim, S. H., Hur, H. J., Yang, H. J., Kim, H. J., Kim, M. J., Park, J. H., et al. (2013). Citrus Junos Tanaka Peel Extract Exerts Antidiabetic Effects via AMPK and PPAR- $\gamma$ Both In Vitro and In Vivo in Mice Fed a High-Fat Diet. Evid. Based Complement. Alternat Med. 2013, 921012. doi:10.1155/2013/921012

Kim, S. Y., Kim, H. J., Lee, M. K., Jeon, S. M., Do, G. M., Kwon, E. Y., et al. (2006). Naringin Time-Dependently Lowers Hepatic Cholesterol Biosynthesis and Plasma Cholesterol in Rats Fed High-Fat and High-Cholesterol Diet. J. Med. Food 9 (4), 582-586. doi:10.1089/jmf.2006.9.582

Kou, G., Zhao, Z., Dong, X., Zhang, Y., Guo, L., and Zhou, Z. (2017). Effects of Citrus Fruits on Blood Lipid Levels: A Systematic Review and Meta- Analysis. Acta Med. Mediterr. 33, 1143-1150. doi:10.19193/0393-6384_2017_6_179

Lamiquiz-Moneo, I., Giné-González, J., Alisente, S., Bea, A. M., Pérez-Calahorra, S., Marco-Benedí, V., et al. (2020). Effect of Bergamot on Lipid Profile in Humans: A Systematic Review. Crit. Rev. Food Sci. Nutr. 60 (18), 3133-3143. doi:10.1080/10408398.2019.1677554

Lee, C. H., Jeong, T. S., Choi, Y. K., Hyun, B. H., Oh, G. T., Kim, E. H., et al. (2001). Anti-atherogenic Effect of Citrus Flavonoids, Naringin and Naringenin, Associated with Hepatic ACAT and Aortic VCAM-1 and MCP-1 in High Cholesterol-Fed Rabbits. Biochem. Biophys. Res. Commun. 284 (3), 681-688. doi:10.1006/bbrc.2001.5001

Lee, G. H., Peng, C., Park, S. A., Hoang, T. H., Lee, H. Y., Kim, J., et al. (2020). Citrus Peel Extract Ameliorates High-Fat Diet-Induced NAFLD via Activation of AMPK Signaling. Nutrients 12 (3), 673. doi:10.3390/nu12030673

Lee, S.-H., Jeong, T.-S., Park, Y. B., Kwon, Y.-K., Choi, M.-S., and Bok, S.-H. (1999). Hypocholesterolemic Effect of Hesperetin Mediated by Inhibition of 3Hydroxy-3-Methylgultaryl Coenzyme a Reductase and Acyl Coenzyme a: Cholesterol Acyltransferase in Rats Fed High-Cholesterol Diet. Nutr. Res. 19 (8), 1245-1258. doi:10.1016/s0271-5317(99)00085-8

Lee, Y. S., Huh, J. Y., Nam, S. H., Moon, S. K., and Lee, S. B. (2012). Enzymatic Bioconversion of Citrus Hesperidin by Aspergillus Sojae Naringinase:
Enhanced Solubility of Hesperetin-7-O-Glucoside with In Vitro Inhibition of Human Intestinal Maltase, HMG-CoA Reductase, and Growth of Helicobacter pylori. Food Chem. 135 (4), 2253-2259. doi:10.1016/j. foodchem.2012.07.007

Ling, Y., Shi, Z., Yang, X., Cai, Z., Wang, L., Wu, X., et al. (2020). Hypolipidemic Effect of Pure Total Flavonoids from Peel of Citrus (PTFC) on Hamsters of Hyperlipidemia and its Potential Mechanism. Exp. Gerontol. 130, 110786. doi:10.1016/j.exger.2019.110786

Lu, M., Cao, Y., Xiao, J., Song, M., and Ho, C. T. (2018). Molecular Mechanisms of the Anti-obesity Effect of Bioactive Ingredients in Common Spices: a Review. Food Funct. 9 (9), 4569-4581. doi:10.1039/c8fo01349g

Lu, Y., Xi, W., Ding, X., Fan, S., Zhang, Y., Jiang, D., et al. (2013). Citrange Fruit Extracts Alleviate Obesity-Associated Metabolic Disorder in High-Fat DietInduced Obese C57BL/6 Mouse. Ijms 14 (12), 23736-23750. doi:10.3390/ ijms 141223736

Mach, F., Baigent, C., Catapano, A. L., Koskinas, K. C., Casula, M., Badimon, L., et al. (2020). 2019 ESC/EAS Guidelines for the Management of Dyslipidaemias: Lipid Modification to Reduce Cardiovascular Risk. Eur. Heart J. 41 (1), 111-188. doi:10.1093/eurheartj/ehz455

Mir, H., Krouf, D., Taleb-Dida, N., Berzou, S., Guenzet, A., and Khelladi, H. (2019). Effects of Citrus Latifolia Extract on Dyslipidemia and Tissues Redox Status in Rats Fed a High-Cholesterol Diet. Nfs 49 (6), 989-999. doi:10.1108/nfs-042018-0110

Mollace, V., Sacco, I., Janda, E., Malara, C., Ventrice, D., Colica, C., et al. (2011). Hypolipemic and Hypoglycaemic Activity of Bergamot Polyphenols: from Animal Models to Human Studies. Fitoterapia 82 (3), 309-316. doi:10.1016/ j.fitote.2010.10.014

Muhtadi, M., Haryoto, H., Azizah, T., Suhendi, A., and Yen, K. (2015). Antidiabetic and Antihypercholesterolemic Activities of Citrus Sinensis Peel: In Vivo Study. Natl. J. Physiol. Pharm. Pharmacol. 5 (5), 382-385. doi:10.5455/njppp.2015.5. 2807201561

Mulvihill, E. E., Allister, E. M., Sutherland, B. G., Telford, D. E., Sawyez, C. G., Edwards, J. Y., et al. (2009). Naringenin Prevents Dyslipidemia, Apolipoprotein B Overproduction, and Hyperinsulinemia in LDL Receptor-Null Mice with Diet-Induced Insulin Resistance. Diabetes 58 (10), 2198-2210. doi:10.2337/ db09-0634

Mulvihill, E. E., and Huff, M. W. (2012). Protection from Metabolic Dysregulation, Obesity, and Atherosclerosis by Citrus Flavonoids: Activation of Hepatic PGC1a-Mediated Fatty Acid Oxidation. PPAR Res. 2012, 857142. doi:10. $1155 / 2012 / 857142$

Onakpoya, I., O’Sullivan, J., Heneghan, C., and Thompson, M. (2017). The Effect of Grapefruits (Citrus Paradisi) on Body Weight and Cardiovascular Risk Factors: A Systematic Review and Meta-Analysis of Randomized Clinical Trials. Crit. Rev. Food Sci. Nutr. 57 (3), 602-612. doi:10.1080/10408398.2014.901292

Page, M. J., McKenzie, J. E., Bossuyt, P. M., Boutron, I., Hoffmann, T. C., Mulrow, C. D., et al. (2021). The PRISMA 2020 Statement: an Updated Guideline for Reporting Systematic Reviews. BMJ 372, n71. doi:10.1136/bmj.n71

Pan, W. W., and Myers, M. G. (2018). Leptin and the Maintenance of Elevated Body Weight. Nat. Rev. Neurosci. 19 (2), 95-105. doi:10.1038/nrn.2017.168

Patil, V. C., Avhad, A. B., Kulkarni, A. R., and Pandere, K. A. (2020). High-Sensitive C-Reactive Protein in Patients with Coronary Artery Disease. J. Nat. Sci. Biol. Med. 11, 39-44. doi:10.4103/jnsbm.JNSBM_159_19

Pepino, M. Y., Kuda, O., Samovski, D., and Abumrad, N. A. (2014). StructureFunction of CD36 and Importance of Fatty Acid Signal Transduction in Fat Metabolism. Annu. Rev. Nutr. 34, 281-303. doi:10.1146/annurev-nutr-071812161220

Pirillo, A., Casula, M., Olmastroni, E., Norata, G. D., and Catapano, A. L. (2021). Global Epidemiology of Dyslipidaemias. Nat. Rev. Cardiol. 18 (10), 689-700. doi:10.1038/s41569-021-00541-4

Pradhan, G., Samson, S. L., and Sun, Y. (2013). Ghrelin: Much More Than a Hunger Hormone. Curr. Opin. Clin. Nutr. Metab. Care 16 (6), 619-624. doi:10. 1097/MCO.0b013e328365b9be

Raasmaja, A., Lecklin, A., Li, X. M., Zou, J., Zhu, G. G., Laakso, I., et al. (2013). A Water-Alcohol Extract of Citrus Grandis Whole Fruits Has Beneficial Metabolic Effects in the Obese Zucker Rats Fed with High Fat/high Cholesterol Diet. Food Chem. 138 (2-3), 1392-1399. doi:10.1016/j. foodchem.2012.09.140 
Rafiq, S., Kaul, R., Sofi, S. A., Bashir, N., Nazir, F., and Ahmad Nayik, G. (2018). Citrus Peel as a Source of Functional Ingredient: A Review. J. Saudi Soc. Agric. Sci. 17, 351. Available at: http://www.sciencedirect.com/science/article/pii/ S1658077X16300960.doi:10.1016/j.jssas.2016.07.006

Sahebkar, A. (2017). Effects of Quercetin Supplementation on Lipid Profile: A Systematic Review and Meta-Analysis of Randomized Controlled Trials. Crit. Rev. Food Sci. Nutr. 57 (4), 666-676. doi:10.1080/10408398.2014.948609

Sato, M., Goto, T., Inoue, E., Miyaguchi, Y., and Toyoda, A. (2019). Dietary Intake of Immature Citrus Tumida Hort. Ex Tanaka Peels Suppressed Body Weight Gain and Fat Accumulation in a Mouse Model of Acute Obesity. J. Nutr. Sci. Vitaminol (Tokyo) 65 (1), 19-23. doi:10.3177/jnsv.65.19

Schulz, I. (2006). Treatment of Dyslipidemia: How and when to Combine Lipid Lowering Drugs. Arq Bras Endocrinol. Metabol 50 (2), 344-359. doi:10.1590/ s0004-27302006000200021

Shin, E. J., Park, J. H., Sung, M. J., Chung, M. Y., and Hwang, J. T. (2016). Citrus Junos Tanaka Peel Ameliorates Hepatic Lipid Accumulation in HepG2 Cells and in Mice Fed a High-Cholesterol Diet. BMC Complement. Altern. Med. 16 (1), 499. doi:10.1186/s12906-016-1460-y

Sowndarya, K., Joseph, J., Shenoy, A., and Hegde, A. (2021). Evaluation of Triglyceride/ high-Density Lipoprotein Ratio as a Surrogate Marker for Insulin Resistance in Healthy Young Males. J. Nat. Sci. Biol. Med. 12 (2), 213-217. doi:10.4103/jnsbm. JNSBM-193-20

T Manuel, C Marco, and G Fred (Editors) (2020). 1st Edition. Available at: https:// www.elsevier.com/books/the-genus-citrus/talon/978-0-12-812163-4.The Genus Citrus

Terpstra, A. H., Lapré, J. A., de Vries, H. T., and Beynen, A. C. (2002). The Hypocholesterolemic Effect of Lemon Peels, Lemon Pectin, and the Waste Stream Material of Lemon Peels in Hybrid F1B Hamsters. Eur. J. Nutr. 41 (1), 19-26. doi:10.1007/s003940200002

Toth, P. P., Patti, A. M., Nikolic, D., Giglio, R. V., Castellino, G., Biancucci, T., et al. (2015). Bergamot Reduces Plasma Lipids, Atherogenic Small Dense LDL, and Subclinical Atherosclerosis in Subjects with Moderate Hypercholesterolemia: A 6 Months Prospective Study. Front. Pharmacol. 6, 299. doi:10.3389/fphar.2015.00299

Tripoli, E., Guardia, M. L., Giammanco, S., Majo, D. D., and Giammanco, M. (2007). Citrus Flavonoids: Molecular Structure, Biological Activity and Nutritional Properties: A Review. Food Chem. 104 (2), 466-479. doi:10. 1016/j.foodchem.2006.11.054

Vinson, J. A., Hu, S.-J., Jung, S., and Stanski, A. M. (1998). A Citrus Extract Plus Ascorbic Acid Decreases Lipids, Lipid Peroxides, Lipoprotein Oxidative
Susceptibility, and Atherosclerosis in Hypercholesterolemic Hamsters. J. Agric. Food Chem. 46 (4), 1453-1459. doi:10.1021/jf970801u

Wiggins, B. S., Dixon, D., Bellone, J., Gasbarro, N., Marrs, J. C., and Tran, R. (2019). Key Articles and Guidelines in the Management of Dyslipidemia: 2019 Update. J. Pharm. Pract. 11, 0897190019868413. doi:10.1177/0897190019868413

Wu, H., Liu, Y., Chen, X., Zhu, D., Ma, J., Yan, Y., et al. (2017). Neohesperidin Exerts Lipid-Regulating Effects In Vitro and In Vivo via Fibroblast Growth Factor 21 and AMP-Activated Protein Kinase/Sirtuin Type 1/Peroxisome Proliferator-Activated Receptor Gamma Coactivator 1a Signaling Axis. Pharmacology 100 (3-4), 115-126. doi:10.1159/000452492

Zeka, K., Ruparelia, K., Arroo, R. R. J., Budriesi, R., and Micucci, M. (2017) Flavonoids and Their Metabolites: Prevention in Cardiovascular Diseases and Diabetes. Diseases 5 (3), 19. doi:10.3390/diseases5030019

Zhao, X., Wang, D., and Qin, L. (2021). Lipid Profile and Prognosis in Patients with Coronary Heart Disease: a Meta-Analysis of Prospective Cohort Studies. BMC Cardiovasc. Disord. 21 (1), 69. doi:10.1186/s12872-020-01835-0

Zulkhairi, H. A., Khairunnuur, A. F., Hafipah, M. R. N., Azrina, A., Rasadah, M. A., Kamilah, K. A. K., et al. (2010). An Aqueous Extract of Citrus Mitis Possesses Antioxidative Properties and Improves Plasma Lipid Profiles in Rat Induced with High Cholesterol Diet. J. Med. Plant Res. 4 (1), 49-57. doi:10.5897/ JMPR09.385

Conflict of Interest: The authors declare that the research was conducted in the absence of any commercial or financial relationships that could be construed as a potential conflict of interest.

Publisher's Note: All claims expressed in this article are solely those of the authors and do not necessarily represent those of their affiliated organizations, or those of the publisher, the editors and the reviewers. Any product that may be evaluated in this article, or claim that may be made by its manufacturer, is not guaranteed or endorsed by the publisher.

Copyright (c) 2022 Carvalho, Nascimento, Nascimento, Gonçalves, Ziegelmann, Tavares and Guimarães. This is an open-access article distributed under the terms of the Creative Commons Attribution License (CC BY). The use, distribution or reproduction in other forums is permitted, provided the original author(s) and the copyright owner(s) are credited and that the original publication in this journal is cited, in accordance with accepted academic practice. No use, distribution or reproduction is permitted which does not comply with these terms. 